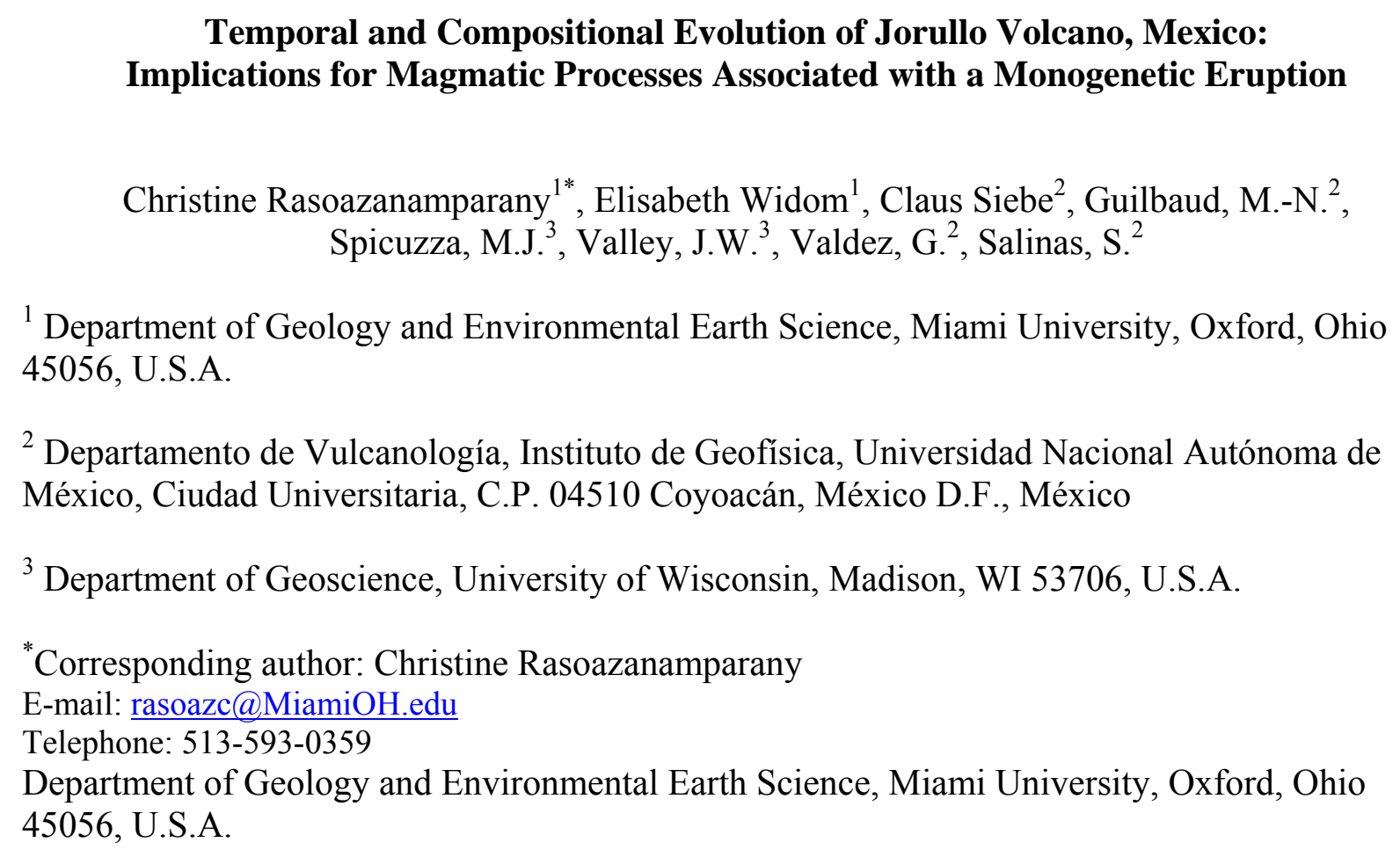

\section{Temporal and Compositional Evolution of Jorullo Volcano, Mexico: Implications for Magmatic Processes Associated with a Monogenetic Eruption}

\author{
Christine Rasoazanamparany ${ }^{1 *}$, Elisabeth Widom ${ }^{1}$, Claus Siebe ${ }^{2}$, Guilbaud, M.-N. ${ }^{2}$, \\ Spicuzza, M.J. ${ }^{3}$, Valley, J.W. ${ }^{3}$, Valdez, G. ${ }^{2}$, Salinas, S. $^{2}$ \\ ${ }^{1}$ Department of Geology and Environmental Earth Science, Miami University, Oxford, Ohio \\ 45056, U.S.A. \\ ${ }^{2}$ Departamento de Vulcanología, Instituto de Geofísica, Universidad Nacional Autónoma de \\ México, Ciudad Universitaria, C.P. 04510 Coyoacán, México D.F., México \\ ${ }^{3}$ Department of Geoscience, University of Wisconsin, Madison, WI 53706, U.S.A. \\ "Corresponding author: Christine Rasoazanamparany \\ E-mail: rasoazc@MiamiOH.edu \\ Telephone: 513-593-0359 \\ Department of Geology and Environmental Earth Science, Miami University, Oxford, Ohio \\ 45056, U.S.A.
}

\title{
Abstract:
}

The 1759-1774 eruption of the Jorullo volcano in the Michoacán Guanajuato Volcanic field (MGVF), Mexico, produced lavas that range in composition from basalt to basaltic andesite. We have conducted new major and trace element and isotopic studies (whole rock Sr-Nd-Pb-Hf-Os, and $\mathrm{O}$ isotopes in olivine separates) of the Jorullo lavas and tephras spanning the duration and compositional range of the eruption, to further constrain the potential roles of mantle source heterogeneity, subduction-related metasomatism, and crustal assimilation in the petrogenesis of the Jorullo magmas. This study presents the first $\mathrm{Hf}$, high precision $\mathrm{Pb}$ and comprehensive oxygen isotope measurements for Jorullo volcanic rocks. All samples have arc-like trace element patterns with enrichments in large ion lithophile elements (e.g. $\mathrm{Ba}, \mathrm{Rb}$, and $\mathrm{Pb}$ ) and depletions in fluid immobile elements (e.g. Nb, Ta). In addition, the samples show variations in ${ }^{87} \mathrm{Sr} /{ }^{86} \mathrm{Sr}$ $(0.7038-0.7040),{ }^{143} \mathrm{Nd} /{ }^{144} \mathrm{Nd}(0.51280-0.51285),{ }^{176} \mathrm{Hf} /{ }^{177} \mathrm{Hf}(0.28297-0.28300),{ }^{206} \mathrm{~Pb} /{ }^{204} \mathrm{~Pb}$ (18.62-18.66), ${ }^{207} \mathrm{~Pb} /{ }^{204} \mathrm{~Pb}$ (15.57-15.59) and ${ }^{208} \mathrm{~Pb} /{ }^{204} \mathrm{~Pb}$ (38.34-38.43). Osmium isotope signatures are, with one exception, more radiogenic than the depleted and primitive mantle $\left({ }^{187} \mathrm{Os} /{ }^{188} \mathrm{Os}=0.1231-0.1616\right)$. Oxygen isotope ratios of olivine phenocrysts $\left(\delta^{18} \mathrm{O}_{\mathrm{SMOW}}=5.70\right.$ $6.02 \%$ ) show limited variation, but are isotopically heavier than normal mantle olivine. The samples define two geochemical groups: high-MgO samples with higher ${ }^{87} \mathrm{Sr}{ }^{86} \mathrm{Sr}$, lower ${ }^{143} \mathrm{Nd} /{ }^{144} \mathrm{Nd}$ and ${ }^{176} \mathrm{Hf} /{ }^{177} \mathrm{Hf}$, and a positive correlation of $\mathrm{Sr}$ and $\mathrm{Pb}$ isotopes; and low-MgO samples displaying lower ${ }^{87} \mathrm{Sr} /{ }^{86} \mathrm{Sr}$ but higher ${ }^{143} \mathrm{Nd} /{ }^{144} \mathrm{Nd}$ and ${ }^{176} \mathrm{Hf} /{ }^{177} \mathrm{Hf}$ than the former group, and a negative correlation of $\mathrm{Sr}$ and $\mathrm{Pb}$ isotopes. The high- $\mathrm{MgO}$ group comprises most of the early tephra and lavas, whereas the low-MgO group includes most of the late tephra and lavas. These compositional variations are inconsistent with shallow level contamination, but rather are interpreted to reflect mantle source heterogeneity. Trace element and isotopic signatures are consistent with North Mexican Extensional Province (NMEP) mantle metasomatised by 
subduction components composed of sediment- and oceanic crust-derived hydrous fluid. The temporal-compositional variations observed in Jorullo magmas are inferred to result from a combination of variable degrees of fractional crystallization of magmas produced by tapping a progressively less metasomatised mantle source that is vertically and/or laterally heterogeneous.

Keywords: Jorullo Volcano, monogenetic volcanism, subduction zone, mantle heterogeneity, isotopes

\section{Introduction}

Small-volume, mafic magmatic systems $\left(<1 \mathrm{~km}^{3}\right)$ produced by single episodes of volcanic activity are referred to as monogenetic volcanic fields (Connor and Conway, 2000). They tend to occur as cinder cones, maars, tuff cones and lava domes. The duration of an individual eruption is typically shorter than that of composite volcanoes (e.g. stratovolcanoes), lasting from several days to years (Connor and Conway, 2000), but the volcanic field as a whole may span millions of years. Because of their small volume and mafic character, they are often considered to ascend very rapidly from their mantle source, and thus provide a key to understanding the magmatic processes that are often masked in larger magmatic systems. Nonetheless, they often show significant compositional variation within individual eruptions as well as among closely spaced eruptive centers. The origin of this compositional variation has been the source of considerable debate. Some studies suggest that the compositional variation reflects heterogeneity in the mantle source (e.g. Blondes et al., 2008; Reiners, 2002; Siebe et al., 2004), whereas others suggest that it is the result of assimilation of lithospheric mantle or crust during ascent (Chesley et al., 2002; Lassiter and Luhr, 2001; Siebe et al., 2004). Furthermore, questions remain about the origin of source heterogeneity including the role of subduction derived fluid and melts. Distinguishing subduction signatures from shallow level crustal assimilation poses a challenge, as both processes can produce similar chemical and isotopic signatures, and both processes may work in concert to produce compositional variations and temporal-compositional trends observed in some basaltic monogenetic eruptions and volcanic fields (Chesley et al., 2002; Siebe et al., 2004; Wallace and Carmichael, 1999). A related issue is the question of whether monogenetic systems develop sustained magma chambers, or whether magmas erupt more-or-less directly from their mantle sources.

The study of the petrogenesis of Jorullo volcano and its satellites cones provides a unique opportunity to evaluate the origin of compositional variation within individual monogenetic centers, as well as magmatic processes operating in subduction systems in general. Jorullo volcano is located within the Michoacán Guanajuato Volcanic Field (MGVF), which represents the volcanic front of the Trans-Mexican Volcanic Belt (TMVB). Previous workers have analyzed Jorullo samples for major and select trace elements (e.g. Lassiter and Luhr, 2001; Luhr and Carmichael 1985), and Sr-Nd-Pb and Os isotopes (e.g. Chesley et al., 2002; Lassiter and Luhr, 2001; Verma and Hasenaka, 2004), and (for one sample only) oxygen isotopes (Johnson et al., 2009), but none covered the full duration or compositional range of the eruption. This study presents the first $\mathrm{Hf}$ isotope and high precision $\mathrm{Pb}$ isotope data for Jorullo samples, as well as an extensive new data set of $\mathrm{Sr}, \mathrm{Nd}$, Os and oxygen isotope analyses spanning the duration of the Jorullo eruption. We use the elemental and isotopic data for the Jorullo lavas and tephra to address the following aspects of their petrogenesis: 1) the influence of crustal assimilation; 2) the types and nature of the subduction components being added to the mantle wedge (sediment 
versus oceanic crust; fluid versus melt); and 3) the cause of the systematic compositional variations with time in the Jorullo eruption.

\section{Tectonic Setting}

The TMVB is an active volcanic arc that trends in an E-W direction, and is approximately $200 \mathrm{~km}$ wide and 1,000 km long. It contains more than 8,000 eruptive vents including stratovolcanoes, calderas, domes, and monogenetic cinder cones. On the basis of available geochronological data, volcanic activity within the belt has occurred since the Miocene (Ferrari et al., 1999). Magmatism is generally accepted to be associated with the subduction of the oceanic Cocos and Rivera Plates beneath the continental North American Plate along the Middle America Trench (Fig. 1). The oblique orientation of the TMVB relative to the Middle American Trench is attributed to near-horizontal subduction of the Cocos plate beneath central Mexico between 100 and $250 \mathrm{~km}$ from the trench, and steep subduction of the Rivera plate to the west (e.g. Pardo and Suárez, 1995). Ferrari (2004) proposed that volcanism has migrated trenchward at a rate of $\sim 10 \mathrm{~km} / \mathrm{Ma}$ over the past $2 \mathrm{Ma}$, due to rollback of the subducted Cocos plate. Volcanism within the belt is compositionally diverse, as both calc-alkaline and intra-plate-type magmas have erupted across the volcanic belt, and in many places they are coeval. The calcalkaline signatures are often considered to be derived from partial melting of the subarc mantle modified by slab melts or slab dehydration (e.g. Blatter et al., 2010; Cai et al., 2014; Petrone et al., 2003; Siebe et al., 2004; Straub et al., 2015). In contrast, the OIB-type magmas have been variously interpreted to represent melts of the unmodified subarc asthenospheric mantle (e.g. Luhr, 1997; Luhr et al., 2006; Siebe et al., 2004), melts of an enriched mantle (EM) source metasomatized by subduction fluid (Petrone et al., 2003), melts of pyroxenitic mantle produced by subduction fluid/melt infiltration (Straub et al., 2008, 2015), or a deep mantle plume (Marquez et al., 1999b; Verma, 2000). Despite the controversy of the origin of the OIB-type magmas, clear subduction signatures are present in most samples and calc-alkaline magmas are volumetrically dominant compared to the OIB-type magmas.

The MGVF represents one of several distinct monogenetic volcanic fields in the TMVB, and is thought to represent the volcanic front of the TMVB (Hasenaka and Carmichael, 1985). Based on hypocenter relocation of local earthquakes, the volcanic field is thought to lie $\sim 80 \mathrm{~km}$ above the subducted Cocos plate (Pardo and Suarez, 1995), and as such, has been regarded as a key area to study the relationship between central Mexican volcanism and subduction of the Cocos plate (e.g. Verma et al., 2002). The MGVF contains more than 1,000 eruptive centers, most of which are located about 200-300 km from the trench (Hasenaka and Carmichael, 1985). Two historic eruptions have occurred within the MGVF, including Jorullo (1759-1774) and Parícutin (1943-1952) volcanoes. The volcanic field consists mostly of monogenetic scoria cones, lava domes, shield volcanoes and maars. In addition, both alkaline and calc-alkaline compositions have erupted throughout the field (Luhr, 1997; Luhr et al., 2006). The origin of these compositionally distinct magmas has been the subject of extensive petrologic and geochemical studies. It has been suggested that the coexistence of calc-alkaline and intraplate alkaline volcanism in close proximity implies that they come from distinct domains in the mantle (Luhr, 1997) in which the intra-plate alkaline basalts are produced by partial melting of a convecting upper mantle uncontaminated by subduction components, whereas the calc-alkaline rocks are derived by melting of subarc mantle wedge that has been metasomatised by slabderived materials (Luhr, 1997). Some studies have also invoked the involvement of crustal 
contamination during petrogenesis (Chesley et al., 2002; Lassiter and Luhr, 2001). Other studies (e.g. Verma et al., 2004) have attributed the origin of the MGVF calc-alkaline rocks in general to partial melting of veined metasomatised mantle sources and suggested that the MGVF might not be related to the subduction of the Cocos plate, but rather to the ongoing rifting processes within the TMVB (e.g. Verma et al., 2004). The origin of magmatism and the petrogenetic processes operating within the MGVF thus remain inconclusive, and are further evaluated in this study.

\section{Jorullo Eruption and Samples}

Jorullo volcano and its satellite cones (Volcán del Norte, an unnamed cone, Volcán de Enmedio, and Volcán del Sur) erupted over a fifteen-year period from 1759 to 1774, and produced pyroclastic deposits and lava flows totaling a volume of approximately $2 \mathrm{~km}^{3}$ (Luhr and Carmichael, 1985; Rowland et al., 2009). Historical accounts reported that the early part of the eruption (from 1759 to $~ 1764$ ) consisted of pyroclastic activity and covered the surrounding area with wet ash fall deposits (Luhr and Carmichael, 1985). The effusion of most of the lava flows occurred between 1760 and 1766 (Gadow, 1930). It was also reported that the pyroclastic activity continued throughout the eruption, and ash fall layers blanket most of the lava flows (Gadow, 1930; Luhr and Carmichael, 1985). Luhr and Carmichael (1985) were the first to document the geology and the compositional evolution of Jorullo lavas over time. They subdivided the lava flows into three stages: early, middle and late. They noted that the Jorullo lavas became progressively more silica-rich over the course of the eruption. This compositional variation was attributed primarily to fractional crystallization of olivine-plagioclase-augite and minor spinel at variable depths within the lower crust to upper mantle (Luhr and Carmichael, 1985).

More recent field mapping has revealed evidence for at least seven distinct eruptive phases (Guilbaud et al., 2009). Based on the new mapping, the earliest lava flows (phases 1 and 2) are thought to have been emitted from multiple vents along a fissure to the southwest of the main Jorullo cone (Fig. 2). Phase three corresponds to the collapse of the South, Middle and North cones and emplacement of related deposits (but no new lava), and lavas from phases four to seven were emitted primarily from the main cone. Pyroclastic activity, emitted primarily from the main cone, occurred throughout the duration of the eruption, but mostly between phases three and four (after collapse of the satellite cones), with minor explosive activity after phase seven. Lavas from all phases of the eruptive sequence (except phase 3 for which no lava was produced) were sampled in order to investigate geochemical and isotopic variations through time during the eruption (Fig. 2). In addition, we excavated two sites located $<1 \mathrm{~km}$ to the south and southeast of the main cone, and sampled tephra deposits that encompass the full range of explosive activity at Jorullo. The lowermost part of the tephra sequence was sampled to the southeast of the main cone and the upper and middle parts of the sequence were recovered just south of the cone. The tephra deposits largely preserve their original stratigraphy and consist mostly of alternating layers of interbedded fine ash and lapilli (Appendix 1). Several samples of the local basement rock (the La Huacana granitoid), which occur as xenoliths in the Jorullo eruptive products, were also collected.

\section{Sample Preparation and Analytical Techniques}


Mineral compositions of olivine and oxide inclusions were determined by wavelengthdispersive X-ray emission microanalysis using a CAMECA SX50 electron microprobe at the Department of Geological Sciences at Indiana University. Conditions of measurement were 15 $\mathrm{keV}$ accelerating voltage, $20 \mathrm{nA}$ beam current, $\sim 1 \mu \mathrm{m}$ beam size and peak counting time of $20 \mathrm{~s}$. The accuracy of the analyses was monitored using an international standard (San Carlos olivine, USNM 1113122/444).

For whole rock major element, trace element and isotopic analyses, we used fresh samples free of xenoliths and alteration. Samples were first cut into thin slabs, ground with siliconcarbide sand paper to remove any metal traces from the rock saw, and cleaned rigorously with 18.2 $\mathrm{M} \Omega \mathrm{H}_{2} \mathrm{O}$ in an ultrasonic bath. The samples were dried in an oven overnight at $110^{\circ} \mathrm{C}$, then crushed and powdered in a high purity alumina shatterbox. For the Jorullo lavas and tephra, major elements and a subset of trace elements ( $\mathrm{Ni}, \mathrm{Cr}, \mathrm{Sc}, \mathrm{V}, \mathrm{Ga}, \mathrm{Cu}$, and $\mathrm{Zn}$ ) were analyzed by $\mathrm{X}$-ray fluorescence spectrometry $(\mathrm{XRF})$ at the Geoanalytical Laboratory at Washington State University, and all other trace element measurements were conducted by inductively coupled plasma mass spectrometry (ICP-MS), also at Washington State University. Details of the sample preparation and analytical procedures are provided on the Geoanalytical Laboratory website http://environment.wsu.edu/facilities/geolab/). For the basement granitoid samples, major element data are from the UNAM dataset (analysis performed by Activation Laboratories, Ancaster, Canada), and trace element data were obtained at Miami University by ICP-MS, following the procedures described in Yu (2011).

$\mathrm{Sr}, \mathrm{Nd}$ and a subset of the $\mathrm{Pb}$ isotope analyses were performed at Miami University. Approximately $100 \mathrm{mg}$ of sample powder was dissolved in $\mathrm{HF}_{-} \mathrm{HNO}_{3}$, and separations of $\mathrm{Pb}, \mathrm{Sr}$, and $\mathrm{Nd}$ from a given sample aliquot were performed by ion exchange chromatography following standard procedures described in detail in Snyder et al. (2005). Isotopic measurements were performed on a Thermo-Finnigan Triton thermal-ionization mass spectrometer (TIMS) at Miami University. Measured ${ }^{87} \mathrm{Sr} /{ }^{86} \mathrm{Sr}$ and ${ }^{143} \mathrm{Nd} /{ }^{144} \mathrm{Nd}$ isotopic ratios by TIMS were corrected for mass fractionation by normalizing to ${ }^{86} \mathrm{Sr} /{ }^{88} \mathrm{Sr}=0.1194$ and ${ }^{146} \mathrm{Nd} /{ }^{144} \mathrm{Nd}=0.7219$. A mass fractionation correction of $0.10 \%$ per amu was used for ${ }^{206} \mathrm{~Pb} /{ }^{204} \mathrm{~Pb},{ }^{207} \mathrm{~Pb} /{ }^{204} \mathrm{~Pb},{ }^{208} \mathrm{~Pb} /{ }^{204} \mathrm{~Pb}$ measured by TIMS. External precision based on long-term two standard deviation (2 SD) reproducibility of the NBS 987 and La Jolla reference materials gave \pm 0.000015 and \pm 0.000007 for ${ }^{87} \mathrm{Sr} /{ }^{88} \mathrm{Sr}$ and ${ }^{143} \mathrm{Nd} /{ }^{144} \mathrm{Nd}$, respectively. The TIMS 2 SD external reproducibility of the NBS 981 standard reference material on ${ }^{206} \mathrm{~Pb} /{ }^{204} \mathrm{~Pb},{ }^{207} \mathrm{~Pb} /{ }^{204} \mathrm{~Pb}$, and ${ }^{208} \mathrm{~Pb} /{ }^{204} \mathrm{~Pb}$ are $\pm 0.014, \pm 0.019$, and \pm 0.063 , respectively. Higher precision $\mathrm{Pb}$ isotopic measurements were obtained for most samples on separate sample dissolutions. These measurements were performed on a $\mathrm{Nu}$ Plasma multicollector inductively coupled plasma mass spectrometer (MC-ICP-MS) at the Department of Terrestrial and Magnetism (DTM), Carnegie Institution of Washington, using the Tl-spike method to correct for instrumental mass bias based on measured ${ }^{205} \mathrm{Tl} /{ }^{203} \mathrm{Tl}$ ratios. Measured ${ }^{204} \mathrm{Hg} /{ }^{202} \mathrm{Hg}$ was used to correct for the isobaric interference of ${ }^{204} \mathrm{Hg}$ on ${ }^{204} \mathrm{~Pb}$. The 2 SD external reproducibility of the NBS 981 standard reference material during the analytical campaign was \pm 0.0018 for ${ }^{206} \mathrm{~Pb} /{ }^{204} \mathrm{~Pb}, \pm 0.0021$ for ${ }^{207} \mathrm{~Pb} /{ }^{204} \mathrm{~Pb}$, and \pm 0.0059 for ${ }^{208} \mathrm{~Pb} /{ }^{204} \mathrm{~Pb}$.

For Hf isotopic analysis, chemical separation of Hf was conducted at Miami University, and isotopic measurements were performed by MC-ICP-MS using the Nu Plasma at DTM. Hf dissolution and purification methods followed the procedures of $\mathrm{Yu}$ (2011) and Connelly et al. (2006), described briefly below. Approximately $150 \mathrm{mg}$ of powder was dissolved, and Hf was then purified by a two-step column method utilizing first BioRad AG50W-X8 resin and then Eichrom TODGA resin (50-100 mesh). The first column removes major elements and rare earth 
elements (REE), and the high field strength elements (HFSE) are eluted. The second purification column separates Hf from the other HFSE. Over the course of the MC-ICP-MS runs, regular analysis of standard reference material JM 475 was performed to correct for mass bias. All samples were normalized to a ${ }^{176} \mathrm{Hf} /{ }^{177} \mathrm{Hf}$ value for JM 475 of 0.282160 . The average measured ${ }^{176} \mathrm{Hf} /{ }^{177} \mathrm{Hf}$ for JM 475 during the period of data collection was 0.282151 , with a reproducibility of \pm 0.000007 .

Os chemistry and mass spectrometry were performed at Miami University. Os separations were carried out using the Carius tube digestion method of Shirey and Walker (1995). Os purification was accomplished through two distillation steps, including a macro-distillation following the procedures of $\mathrm{Yu}$ (2011) modified from the method of Nägler and Frei (1997), and a micro-distillation using the procedure of Roy-Barman (1993) and Roy-Barman and Allègre (1995). Os isotopic ratios and concentrations were measured by negative ion TIMS (N-TIMS). Samples were loaded onto single Pt filaments with a Ba-hydroxide activator, and measured as $\mathrm{OsO}_{3}{ }^{-}$molecular ions by peak hopping on a single secondary electron multiplier. All measured Os isotope ratios were corrected for mass fractionation using ${ }^{192} \mathrm{Os} /{ }^{188} \mathrm{Os}=3.0826$, and corrected for oxygen isotopic composition using the values of Nier (1950). The external reproducibility for ${ }^{187} \mathrm{Os} /{ }^{188} \mathrm{Os}$ measurements based on the long-term reproducibility of a NIST Os solution standard is \pm 0.0002 . However, internal errors for ${ }^{187} \mathrm{Os} /{ }^{188} \mathrm{Os}$ measurements of the samples were variable and ranged from $0.03-0.15 \%$.

Olivine separates for oxygen isotope measurements were prepared at Miami University, and were free of cracks and alteration, and contained $<1 \%$ oxide inclusions. Olivines were separated from their host lavas and tephras by crushing and sieving to a fraction of $\sim 200 \mu \mathrm{m}$ and handpicked from the sieved fraction under a binocular microscope. The handpicked grains were further crushed with an alumina mortar and pestle and passed through a Frantz magnetic separator to remove crystal fragments with high concentrations of oxide inclusions. To ensure removal of mineral fractions with oxide inclusions or coatings of matrix, the separates were further handpicked under a binocular microscope. The separates were then cleaned three times in an ultrasonic bath with $18.2 \mathrm{M} \Omega \mathrm{H}_{2} \mathrm{O}$. Oxygen isotope measurements were performed at the University of Wisconsin on a Finnigan MAT 251 mass spectrometer, following the methods outlined in Valley et al. (1995). Approximately 2 to $3 \mathrm{mg}$ of olivine was loaded into the fluorination chamber pre-fluorinated prior to analysis. Gore Mountain garnet standard UWG-2 was run with the samples to monitor the precision and accuracy of the analyses. The reproducibility of the UWG-2 garnet standard obtained during the period of analyses was $5.79 \pm 0.12 \%$ ( $2 \mathrm{SD}$ ). The $\delta^{18} \mathrm{O}$ values of the samples were corrected based on the UWG-2 standard values obtained on the same day, in comparison to the accepted value of $5.80 \% \mathrm{~V}$ SMOW.

\section{Results}

\subsection{Petrography and mineral chemistry}

The petrography and mineralogy of the Jorullo lavas, tephra and granitoid inclusions have been described in detail (Luhr and Carmichael, 1985; Guilbaud et al., 2011). Jorullo lavas analyzed in this study are porphyric with $<10 \%$ by volume of euhedral and skeletal phenocrysts of olivine. Groundmass textures range from trachytic to subophitic or interstitial with 
microcrysts of plagioclase, augite, olivine, and spinel. Cr-spinel inclusions are present in most olivine phenocrysts.

Olivine phenocrysts are mostly normally zoned with core to rim Fo contents ranging from 90 to 80 in the early lavas, and 87 to 79 in the late lavas (Appendix 2). Inverse zoning was not observed in the olivines analyzed. The Fo contents of the microphenocrysts are similar to those of the rims of the phenocrysts. Most of the olivines have compositions in or close to equilibrium with their host (based on whole rock compositions), using $\mathrm{K}_{D}^{F e-M g}$ of $0.3 \pm 0.03$ of Roeder and Emslie (1970).

\subsection{Major and trace elements}

Major and trace element data from this study are presented in Table 1. Chemical analyses for other Jorullo samples previously analyzed at Activation Laboratories, Ancaster (UNAM-dataset) are provided in Appendix 3. The Jorullo tephra and lavas range in composition from relatively primitive basalt to basaltic andesite, with $\mathrm{SiO}_{2}$ contents between 52 and 55\% and $\mathrm{MgO}$ ranging from 4.7 to $10.3 \%$. Tephra samples encompass the full compositional range of the eruption, and mostly fall within the range of the lavas. As observed by Luhr and Carmichael (1985), the Jorullo lavas generally became richer in $\mathrm{SiO}_{2}$ as the eruption progressed, although based on the new mapping (Guilbaud et al., 2011) the lavas appear to reflect a somewhat more complex compositional evolution in $\mathrm{SiO}_{2}$ and $\mathrm{MgO}$ with time (Fig. 3a). Likewise, the tephra sequences do not exhibit a strictly monotonic variation in $\mathrm{SiO}_{2}$ or $\mathrm{MgO}$ content with stratigraphic height (Fig. 3b), especially among those with high $\mathrm{MgO}$ contents $(>8 \%)$. Nonetheless, the new data are in general agreement with the previous findings that the early tephra and lavas are relatively primitive, and the late eruptive products more evolved.

Clear correlations between whole rock major oxides are also apparent (Fig. 4). $\mathrm{SiO}_{2}, \mathrm{Al}_{2} \mathrm{O}_{3}$, $\mathrm{Na}_{2} \mathrm{O}, \mathrm{K}_{2} \mathrm{O}$ increase with decreasing $\mathrm{MgO}$, whereas $\mathrm{CaO}$ and $\mathrm{FeO}(\mathrm{t})$ decrease with decreasing $\mathrm{MgO}$. In contrast, $\mathrm{TiO}_{2}$ shows variable behavior: the samples with $\mathrm{MgO}>8 \%$ tend to have lower $\mathrm{TiO}_{2}$ contents $(0.7-0.8 \%)$ and show negative correlation with $\mathrm{MgO}$, whereas the samples with $\mathrm{MgO}$ contents $<8 \%$ exhibit higher $\mathrm{TiO}_{2}(0.92-0.98 \%)$ and display positive correlation with $\mathrm{MgO}$. Samples with high $\mathrm{MgO}(>8 \%)$ are also characterized by relatively high $\mathrm{Ni}(\sim 200-270$ ppm) and $\mathrm{Cr}(\sim 500-585 \mathrm{ppm})$, whereas samples with low $\mathrm{MgO}$ contents $(<8 \%)$ extend to lower $\mathrm{Ni}(\sim 46-150 \mathrm{ppm})$ and $\mathrm{Cr}(\sim 85-290 \mathrm{ppm})$.

Whole rock trace element abundances also correlate with $\mathrm{MgO}$. Incompatible elements such as $\mathrm{La}, \mathrm{Ba}$, and $\mathrm{Sr}$, exhibit negative correlations with $\mathrm{MgO}$, as does $\mathrm{La} / \mathrm{Yb}$ (Fig. 5a-f), whereas compatible trace elements such as $\mathrm{Ni}$ and $\mathrm{Cr}$ (and $\mathrm{Sc}$, not shown) exhibit positive correlations with $\mathrm{MgO}$. All samples have low $\mathrm{Ce} / \mathrm{Pb}(<10)$ and $\mathrm{Nb} / \mathrm{U}(<20)$ relative to $\mathrm{MORB}$ and OIB (Fig. 5g, h), but similar to those of island arc basalts and continental crust. As a whole, the Jorullo samples do not display any clear correlation between $\mathrm{Ce} / \mathrm{Pb}$ or $\mathrm{Nb} / \mathrm{U}$ and $\mathrm{MgO}$, although a slight decrease in $\mathrm{Ce} / \mathrm{Pb}$ and $\mathrm{Nb} / \mathrm{U}$ with decreasing $\mathrm{MgO}$ is observed for samples with $<8 \% \mathrm{MgO}$. All Jorullo samples are marked by slight enrichment in light rare earth elements (LREE) but depletion in heavy rare earth elements (HREE) relative to normal mid-oceanic basalts (N-MORB). In addition, on a MORB-normalized multi-element diagram (Fig. 6), the samples exhibit typical arc trace element patterns with enrichments of fluid-mobile large ion lithophile elements (LILE) such as $\mathrm{Cs}, \mathrm{Rb}, \mathrm{K}, \mathrm{Ba}, \mathrm{Pb}$, and $\mathrm{Sr}$, and depletions in high-fieldstrength elements (HFSE) such as $\mathrm{Nb}$ and Ta. However, the samples exhibit little to no anomaly 
in $\mathrm{Hf}$ concentration $\left(\mathrm{Hf} / \mathrm{Hf}^{*} \sim 0.96-1.04\right.$, where $\left.\mathrm{Hf} / \mathrm{Hf}^{*}=\mathrm{Hf}_{\mathrm{N}} /\left[\mathrm{Nd}_{\mathrm{N}}+\mathrm{Sm}_{\mathrm{N}}\right) / 2\right]$; Wade et al., 2005).

\subsection{Isotopes}

The Sr-Nd-Pb-Hf-Os and oxygen isotope compositions of the Jorullo samples are listed in Table 1. Jorullo samples display significant ranges in ${ }^{87} \mathrm{Sr} /{ }^{86} \mathrm{Sr},{ }^{143} \mathrm{Nd} /{ }^{144} \mathrm{Nd},{ }^{176} \mathrm{Hf} /{ }^{177} \mathrm{Hf}$, and $\mathrm{Pb}$ isotopes (Fig. 7), but exhibit a relatively limited range in ${ }^{187} \mathrm{Os} /{ }^{188} \mathrm{Os}$, and have essentially uniform $\delta^{18} \mathrm{O}_{\text {olivine }}$ (Fig. 8). ${ }^{87} \mathrm{Sr} /{ }^{86} \mathrm{Sr}$ ranges from $0.70376-0.70402,{ }^{143} \mathrm{Nd} /{ }^{144} \mathrm{Nd}$ from 0.512804 - 0.512853, and ${ }^{176} \mathrm{Hf} /{ }^{177} \mathrm{Hf}$ from $0.282969-0.282999$. Pb isotope ratios vary as follows: ${ }^{206} \mathrm{~Pb} /{ }^{204} \mathrm{~Pb}=18.618-18.659,{ }^{207} \mathrm{~Pb} /{ }^{204} \mathrm{~Pb}=15.572-15.591$, and ${ }^{208} \mathrm{~Pb} /{ }^{204} \mathrm{~Pb}=38.336-38.425$. ${ }^{187} \mathrm{Os} /{ }^{188} \mathrm{Os}$ ratios range from $0.1231-0.1616$ over a range in Os concentrations from $6-173 \mathrm{ppt}$, but samples with $>10$ ppt Os range only from $0.1231-0.1407$. All samples except JOR-1290E are characterized by more radiogenic ${ }^{187} \mathrm{Os} /{ }^{188}$ Os than depleted MORB mantle and primitive upper mantle values. Likewise, olivine $\delta^{18} \mathrm{O}$ values (full range 5.70-6.02\%o; most $\sim 5.8 \pm 0.1 \%$ ) are all higher than the oxygen isotope compositions typical of depleted MORB mantle olivine (5.2 $\pm 0.2 \%$; e.g. Mattey et al., 1994; Eiler, 2001).

In general, the $\mathrm{Sr}, \mathrm{Nd}, \mathrm{Pb}, \mathrm{Os}$, and oxygen isotopic compositions are similar to those determined in previous studies (e.g. Lassiter and Luhr, 2001; Chesley et al., 2002; Verma and Hasenaka, 2004; Johnson et al., 2009), and fall within the isotopic ranges of the MGVF and other regions of the volcanic front as well as the TMVB in general as recorded in the comprehensive MexPet database of Luhr et al., 2006. On ${ }^{207} \mathrm{~Pb} /{ }^{204} \mathrm{~Pb}$ vs. ${ }^{206} \mathrm{~Pb} /{ }^{204} \mathrm{~Pb}$ and ${ }^{208} \mathrm{~Pb} /{ }^{204} \mathrm{~Pb}$ vs. ${ }^{206} \mathrm{~Pb} /{ }^{204} \mathrm{~Pb}$ diagrams (Fig. 7), the Jorullo samples plot above the North Hemisphere Reference Line (NHRL; Hart 1984). They are compositionally intermediate between local subducting terrigenous and pelagic sediments from DSDP Site 487, but significantly more radiogenic than the subducting oceanic crust and East Pacific Rise (EPR) basalts. All samples fall along the terrestrial mantle-crust array in $\mathrm{Hf}-\mathrm{Nd}$ isotope space, and are characterized by lower $\mathrm{Hf}$ and $\mathrm{Nd}$ isotope signatures than DMM and basalts from DSDP site 487, but higher $\mathrm{Hf}$ and $\mathrm{Nd}$ isotope signatures than the local subducting terrigenous and pelagic sediments.

The Jorullo samples define an overall negative correlation between ${ }^{87} \mathrm{Sr} /{ }^{86} \mathrm{Sr}$ and ${ }^{143} \mathrm{Nd} /{ }^{144} \mathrm{Nd}$ (Fig. 9a), although in detail, samples with $\mathrm{MgO}>8 \%$ form a slightly steeper array than samples with $\mathrm{MgO}<8 \%$. Both arrays trend toward the compositions of the local granitic basement and Mexican lower crustal xenoliths. Notably, the higher-MgO samples have the most radiogenic ${ }^{87} \mathrm{Sr} /{ }^{86} \mathrm{Sr}$ and lowest ${ }^{143} \mathrm{Nd} /{ }^{144} \mathrm{Nd}$, while the lower-MgO samples are offset towards lower ${ }^{87} \mathrm{Sr} /{ }^{86} \mathrm{Sr}$ and higher ${ }^{143} \mathrm{Nd} /{ }^{144} \mathrm{Nd}$ isotopic compositions. Distinctions between the lowerand higher-MgO samples are most pronounced on a ${ }^{206} \mathrm{~Pb} /{ }^{204} \mathrm{~Pb}$ versus ${ }^{87} \mathrm{Sr} /{ }^{86} \mathrm{Sr}$ diagram (Fig. 9b), in which they form a negative and positive correlation, respectively. However, the lowestMgO sample (JOR-0766), which represents the final phase of eruption at Jorullo, has similar trace element and isotopic characteristics to those of the highest-MgO samples. None of the isotope systems correlate with indices of differentiation such as $\mathrm{MgO}$ or $\mathrm{Ni}$, and no correlation is observed between ${ }^{187} \mathrm{Os} /{ }^{188}$ Os and the other isotope systems.

\section{Discussion}

On the basis of the new major element, trace element, and Sr-Nd-Pb-Hf isotope data presented in this study, distinct geochemical and isotopic systematics are observed for samples 
with $>8 \% \mathrm{MgO}$ versus those with $<8 \% \mathrm{MgO}$. For simplicity, we refer to these hereafter as the "high-MgO" and "low-MgO" groups, respectively, although we emphasize that this designation does not bear on whether or not the groups are cogenetic. The high-MgO group comprises the early tephra and lavas and is characterized by more primitive $(\mathrm{Ni}>200 \mathrm{ppm}$ and $\mathrm{Cr}>500 \mathrm{ppm})$ compositions, and higher ${ }^{87} \mathrm{Sr} /{ }^{86} \mathrm{Sr}$ but lower ${ }^{143} \mathrm{Nd} /{ }^{144} \mathrm{Nd}$ and ${ }^{176} \mathrm{Hf} /{ }^{177} \mathrm{Hf}$ isotope ratios. The low-MgO group includes the late tephra and lavas and is characterized by more evolved compositions ( $\mathrm{Ni}<200 \mathrm{ppm}, \mathrm{Cr}<500 \mathrm{ppm}$ ), lower ${ }^{87} \mathrm{Sr} /{ }^{86} \mathrm{Sr}$ and higher ${ }^{143} \mathrm{Nd} /{ }^{144} \mathrm{Nd}$ and ${ }^{176} \mathrm{Hf} /{ }^{177} \mathrm{Hf}$ ratios than the high-MgO samples. The Jorullo samples show a broad negative correlation in ${ }^{87} \mathrm{Sr} /{ }^{86} \mathrm{Sr}$ vs. ${ }^{143} \mathrm{Nd} /{ }^{144} \mathrm{Nd}$ (Fig. 9a), with the high-MgO group forming an array with a steeper slope than the low-MgO group. Similarly, on the ${ }^{206} \mathrm{~Pb} /{ }^{204} \mathrm{~Pb}$ vs. ${ }^{87} \mathrm{Sr} /{ }^{86} \mathrm{Sr}$ diagram (Fig. 9b), the high-MgO and low-MgO samples form positive and negative correlations, respectively. Possible models to explain the temporal-compositional changes and the observed isotopic variations of the eruptive products include: 1) fractional crystallization with variable crustal assimilation; and 2) tapping of a heterogeneous mantle source in which different components predominate throughout the eruption.

\subsection{Fractional crystallization}

Major and trace element trends of Jorullo tephra and lavas are generally compatible with closed system fractionation. Marked increases in $\mathrm{SiO}_{2}$ and $\mathrm{Al}_{2} \mathrm{O}_{3}$ and the decrease in $\mathrm{Ni}$ and $\mathrm{Cr}$ with decreasing $\mathrm{MgO}$ (Fig. 4) are consistent with fractionation of olivine. The general decrease in $\mathrm{CaO} / \mathrm{Al}_{2} \mathrm{O}_{3}, \mathrm{CaO}$, and $\mathrm{Sc}$ concentrations (not shown) with decreasing $\mathrm{MgO}$ are further indicative of clinopyroxene fractionation. In addition, the change from increasing to decreasing $\mathrm{TiO}_{2}$ in the high- and low-MgO groups, respectively, indicates that oxides became important in the fractionating mineral assemblage at $\mathrm{MgO}<8 \%$. Although Luhr and Carmichael (1985) proposed fractionation of olivine + clinopyroxene + plagioclase + minor spinel to explain the major and trace element variations of the products of Jorullo, the lack of decrease in $\mathrm{Al}_{2} \mathrm{O}_{3}$ or $\mathrm{Sr}$ with decreasing $\mathrm{MgO}$ (Figs. 4, 5), and the lack of negative Eu anomalies (Fig. 6), suggest that plagioclase was not a major fractionating phase, in accord with the petrographic observation that plagioclase phenocrysts are absent in most of the samples. Johnson et al. (2008) further suggested a role for amphibole fractionation based on major element modeling. Although amphibole is observed in the phenocryst assemblage only in the very most evolved Jorullo lavas (e.g. JOR-0766), it may have been segregated from residual magmas at depth as has been commonly proposed for arc magmas ("cryptic fractionation", e.g. Davidson et al., 2007; Johnson et al., 2008), and/or it may be a relatively late stage addition to the fractionating mineral assemblage. The increasing $\mathrm{La} / \mathrm{Yb}$ with decreasing $\mathrm{MgO}$ (Fig. 5f; caused by increasing La with essentially constant $\mathrm{Yb}$ ) is consistent with the relative Kd's for amphibole, which preferentially incorporates HREE relative to LREE (Blundy and Wood, 2003; Davidson et al., 2007). Crystallization of amphibole would indicate fractionation at mid-crustal depths (Davidson et al., 2007; Johnson et al., 2008).

The increase in highly incompatible element abundances such as $\mathrm{La}, \mathrm{Ba}, \mathrm{Nb}, \mathrm{Zr}, \mathrm{Rb}$ with decreasing $\mathrm{MgO}$ is consistent with closed system fractional crystallization of one or more similar parental magmas, although variable degrees of partial melting of a common source or assimilation-fractional crystallization (AFC) might alternatively explain these trends. Variable degrees of partial melting can fractionate elements with different compatibilities, such as La/Yb, thus the increase in $\mathrm{La} / \mathrm{Yb}$ with decreasing $\mathrm{MgO}$ (Fig. 5f) could potentially be explained by such 
a mechanism. However, the variable $\mathrm{Ce} / \mathrm{Pb}$ and $\mathrm{Nb} / \mathrm{U}$ cannot be explained by this mechanism due to the identical partition coefficients during mantle melting for $\mathrm{Ce}-\mathrm{Pb}$ and $\mathrm{Nb}-\mathrm{U}$, respectively (Hofmann et al., 1986). Fractionation of amphibole, which preferentially incorporates $\mathrm{Pb}$ relative to $\mathrm{Ce}$ and $\mathrm{Nb}$ relative to $\mathrm{U}$ (Romick et al., 1992; GERM database http://earthref.org/GERM/) could explain the slight decrease in $\mathrm{Ce} / \mathrm{Pb}$ and $\mathrm{Nb} / \mathrm{U}$ with decreasing $\mathrm{MgO}$ among the low-MgO group samples. Nevertheless, the very low $\mathrm{Ce} / \mathrm{Pb}$ and $\mathrm{Nb} / \mathrm{U}$ for both the low- and high-MgO group Jorullo samples relative to MORB and OIB (Figs. 5g, h) requires crustal involvement in the petrogenesis of the Jorullo magmas, whether by shallow level contamination or by crustal recycling into the mantle.

\subsection{Crustal assimilation}

Previous geochemical and isotopic studies have proposed respectively that either upper or lower crustal contamination is an important process in the petrogenesis of the MGVF volcanic rocks including Jorullo (e.g. Chesley et al., 2002; Johnson et al., 2008; Lassiter and Luhr, 2001). Likewise, several aspects of our new data could potentially be indicative of crustal assimilation by mantle melts, including the negative correlation of ${ }^{87} \mathrm{Sr} /{ }^{86} \mathrm{Sr}$ and ${ }^{143} \mathrm{Nd} /{ }^{144} \mathrm{Nd}$, low $\mathrm{Ce} / \mathrm{Pb}$ and $\mathrm{Nb} / \mathrm{U}$ ratios, suprachondritic ${ }^{187} \mathrm{Os} /{ }^{188} \mathrm{Os}$ ratios, and high $\delta{ }^{18} \mathrm{O}_{\text {olivine. The higher }}{ }^{87} \mathrm{Sr} /{ }^{86} \mathrm{Sr}$ and lower ${ }^{143} \mathrm{Nd} /{ }^{144} \mathrm{Nd}$ in the high-MgO samples relative to the low-MgO samples are, however, opposite that expected by progressive assimilation-fractional crystallization (AFC) of a single evolving magma. This could alternatively reflect significant crustal contamination of the hotter, high-MgO samples, and lesser contamination of the cooler, low-MgO samples as would be predicted in the case of assimilation equilibrium crystallization (AEC; Devey and Cox, 1987). However, this process is unlikely to operate in small volume magmatic systems such as Jorullo (Huppert and Sparks, 1985). Furthermore, the lack of correlation of $\mathrm{Sr}$ or $\mathrm{Nd}$ isotopes or other potential indices of contamination (e.g. $\mathrm{Rb} / \mathrm{Sr}, \mathrm{Ce} / \mathrm{Pb}, \mathrm{Nb} / \mathrm{U}$ ) with indices of fractionation (e.g. $\mathrm{MgO}$ and $\mathrm{Ni}$ ) among the high-MgO group samples argues against an important role for either AEC or AFC (Appendix 4). To the contrary, the high-MgO samples with $\mathrm{Sr}$ and $\mathrm{Nd}$ isotopic signatures closest to those of the crustal basement comprise the most primitive magmas observed in Jorullo (e.g. Ni $>200 \mathrm{ppm}, \mathrm{Cr}>500 \mathrm{ppm}$ ), which is inconsistent with these magmas having undergone significant differentiation or assimilation. Although Johnson et al. (2008) inferred based on major and trace element (e.g. La, Zr, and Y) systematics of olivine melt inclusions that shallow assimilation of the La Huacana granitic bedrock played an important role in the compositional variations of Jorullo magmas, the Jorullo samples do not trend towards the local granitic crust in $\mathrm{Nd}$ and $\mathrm{Hf}$ isotope space, but rather towards lower ${ }^{176} \mathrm{Hf} /{ }^{177} \mathrm{Hf}$ signatures (Fig. 7).

Prior studies of the MGVF have suggested alternatively that lower crustal assimilation may play a role in their petrogenesis, based on a correlation of ${ }^{187} \mathrm{Os} /{ }^{188} \mathrm{Os}$ with indices of fractionation (e.g. MgO and Ni; Chesley et al., 2002; Lassiter and Luhr, 2001). For Jorullo samples, no correlation between ${ }^{187} \mathrm{Os} /{ }^{188} \mathrm{Os}$ and $\mathrm{MgO}$ or $\mathrm{Ni}$ is observed, either within the sample suite as a whole or within the high-MgO or low-MgO subgroups (Fig. 8a). Rather, the Jorullo samples have relatively low and constant ${ }^{187} \mathrm{Os} /{ }^{188}$ Os compared to other MGVF samples, despite the similarly large range in Ni contents (46 - $270 \mathrm{ppm})$. AFC modeling using the assimilant composition and all other parameters from the Chesley et al. (2002) study fail to reproduce the essentially constant ${ }^{187} \mathrm{Os} /{ }^{188} \mathrm{Os}$ of the Jorullo samples including those with low Ni (Fig. 8a). The $\delta^{18} \mathrm{O}_{\text {olivine }}$ signatures of the Jorullo samples also are essentially homogenous within the $2 \mathrm{SD}$ 
measurement error (with only one exception, $5.82 \pm 0.12 \%$; Fig. 8b), further arguing against a significant role for lower (or upper) crustal assimilation as the cause for the variability in chemical and radiogenic isotope compositions. Likewise, the Jorullo samples lie essentially parallel to the MORB-OIB array on Hf-Nd isotope space, inconsistent with significant assimilation of the low $\Delta \varepsilon_{\mathrm{Hf}}$ (deviation from the MORB-OIB array) Mexican lower crust (Fig. 7). Therefore, we consider the chemical and isotopic variations more likely to be a result of mantle source heterogeneity, for which we explore the petrogenetic implications below.

\subsection{Mantle source heterogeneity}

Jorullo lavas and tephra define two distinct trends in ${ }^{87} \mathrm{Sr} /{ }^{86} \mathrm{Sr}-{ }^{206} \mathrm{~Pb} /{ }^{204} \mathrm{~Pb}$ space (Fig. 9b), with the high- $\mathrm{MgO}$ samples forming a positive trend and the low-MgO samples a negative trend, intersecting at low ${ }^{206} \mathrm{~Pb} /{ }^{204} \mathrm{~Pb}$ and intermediate ${ }^{87} \mathrm{Sr} /{ }^{86} \mathrm{Sr}$. The two trends are also evident in ${ }^{87} \mathrm{Sr} /{ }^{86} \mathrm{Sr}-{ }^{143} \mathrm{Nd} /{ }^{144} \mathrm{Nd}$ space (Fig. 9a), in which the high-MgO group forms a negative trend with a slightly steeper slope than that of the low-MgO group. These observed trends indicate that at least three components contributed to Jorullo magma petrogenesis. Trace element characteristics of both the low-MgO and high-MgO sample groups, including LILE enrichments and HFSE depletions, strongly suggest the involvement of subduction-related hydrous fluid in their petrogenesis. Heavy $\delta^{18} \mathrm{O}_{\text {Olivine }}$ in Jorullo $(5.82 \pm 0.12 \%$ ) compared to that of the depleted mantle (5.2 \pm 0.2\%o; Mattey et al., 1994; Eiler, 2001) suggests significant involvement of sediment and/or uppermost (low-temperature) altered oceanic crust in the Jorullo mantle. We therefore explore below whether the heterogeneous trace element and radiogenic isotope signatures in the Jorullo magmas could be generated by addition of subduction components to a homogeneous pre-subduction mantle wedge.

The pre-subduction mantle composition beneath the TMVB is most often interpreted to be similar to the mantle source of the mafic alkaline volcanism that occurs behind the arc in the Northern Mexican Extensional Province (referred to as NMEP-type mantle by Luhr et al., 2006). The NMEP, known also as the Eastern Alkaline Province or Mexican Basin and Range, is a broad extensional region that extends from near the USA-Mexico border southward to $21^{\circ} \mathrm{N}$ latitude, where it intersects the TMVB (Luhr et al., 2006). The NMEP back-arc mantle is thought to advect into the sub-arc environment by slab-induced convection (e.g. Siebe et al., 2004). Calcalkaline magmas, volumetrically dominant throughout the TMVB, as well as more rare lamprophyre magmas, are interpreted to be derived from partial melting of subduction modified NMEP (Luhr, 1997; Luhr et al., 2006; Siebe et al., 2004; Wallace and Carmichael, 1999) or DMM sources (Petrone et al., 2003). Although the Jorullo samples all have higher ${ }^{87} \mathrm{Sr} /{ }^{86} \mathrm{Sr}$ than $\mathrm{NMEP}$, the low-MgO sample group trends towards NMEP compositions in $\mathrm{Sr}-\mathrm{Pb}$ and $\mathrm{Sr}-\mathrm{Nd}$ isotope space (Fig. 9), suggesting that the source of the Jorullo samples could potentially be produced by addition of subduction components to the NMEP source. The two trends defined by the low-MgO and high-MgO groups could therefore be explained by input of one subduction component $\left(\mathrm{SC}_{1}\right)$ characterized by lower ${ }^{206} \mathrm{~Pb} /{ }^{204} \mathrm{~Pb}$ but higher ${ }^{87} \mathrm{Sr} /{ }^{86} \mathrm{Sr}$ into the NMEP mantle to generate the source of the low-MgO group, and subsequent addition of another subduction component $\left(\mathrm{SC}_{2}\right)$ with higher ${ }^{87} \mathrm{Sr} /{ }^{86} \mathrm{Sr}$ and ${ }^{206} \mathrm{~Pb} /{ }^{204} \mathrm{~Pb}$ to the already metasomatised NMEP mantle to produce the source of the high-MgO group.

In order to investigate which subduction components and processes might best produce the range of trace element and isotopic compositions observed in Jorullo, we have conducted modeling of the Jorullo trace element and isotope data using the inferred composition of the 
NMEP mantle source and the compositions of subducting sediment and altered basaltic oceanic crust (AOC) dredged from the DSDP site 487, assumed to represent the materials being subducted beneath the TMVB (e.g. Gómez-Tuena et al., 2003; Gómez-Tuena et al., 2007, Cai et al., 2014). In our model, the NMEP mantle source is assumed to have isotopic signatures within the range of basalts from the NMEP, but to have a depleted mantle (DMM) trace element composition as suggested by many previous studies (e.g. Ferrari et al., 2001; Petrone et al., 2003; Petrone and Ferrari, 2008; Orozoco et al., 2007; Johnson et al., 2009) (Appendix 5). The sediment column from DSDP site 487 includes $\sim 105 \mathrm{~m}$ of primarily hemipelagic or terrigenous sediment, overlying $\sim 70 \mathrm{~m}$ of late Miocene to Pliocene pelagic sediment, which in turn overlies $\sim 15$ Ma basaltic oceanic crust (Verma, 2000). The isotopic compositions of these potential subduction components are highly variable, and the AOC and sediments generally bracket the range of compositions of the Jorullo samples (Fig. 7). In the modeling presented here, we have estimated the compositions of possible components that could be released from the subducting Cocos plate using the isotopic and elemental compositions of locally subducting materials, as well as experimentally determined mobilities for trace elements during subduction dewatering and melting. The chemical and isotopic compositions of the sediment and basaltic oceanic crust have been reported by Verma et al., 2000, Gómez-Tuena et al., 2003; Lagatta, 2003, GómezTuena et al., 2007, and Cai et al., 2014. The trace element composition of oceanic crust-derived fluid was calculated by using the mobility data of Kessel et al. (2005) at $700^{\circ} \mathrm{C}$ and $4 \mathrm{GPa}$, which are appropriate for dehydration of metabasalt, and for sediment-derived fluid and melt we have used the $\mathrm{D}$ values at $650^{\circ} \mathrm{C}$ and $900^{\circ} \mathrm{C}$ at $2 \mathrm{GPa}$ from the datasets of Johnson and Plank (1999). The total extraction of hydrous fluid during dehydration was assumed to be $1.5 \mathrm{wt} . \%$ in both oceanic crust and sediment, based on the results of high-pressure dehydration experiments on amphibolite (Tatsumi and Kogiso, 1997). All parameters used in the model are given in Appendix 5.

Simple mass balance, assuming an NMEP mantle wedge with a normal $\delta^{18} \mathrm{O}$ of $5.2 \%$, and the isotopically heaviest potential subduction component (sediment with $\delta^{18} \mathrm{O}$ of $20 \%$; e.g. Kolodny et al., 1976; Muehlenbachs, 1986;), requires that $\geq 3 \%$ subduction-derived oxygen be added to the Jorullo mantle source to generate the lowest measured $\delta^{18} \mathrm{O}_{\text {olivine }}$ of 5.7\%o. A likely maximum amount of subduction component can be estimated assuming addition of pure AOCderived component from the low-temperature altered portion of the subducting upper oceanic crust, which has an average $\delta^{18} \mathrm{O}$ signature of $10 \%$ (Staudigel et al., 1995); this would require that no more than $13 \%$ subduction-derived oxygen be added to the Jorullo mantle source.

In order to further evaluate the amount and relative importance of the potential subducted materials that might contribute to the source of the Jorullo magmas, we first consider the isotopic signatures of the most fluid mobile elements, $\mathrm{Sr}$ and $\mathrm{Pb}$. Because the AOC from DSDP site 487 is rather unradiogenic in ${ }^{87} \mathrm{Sr} /{ }^{86} \mathrm{Sr}(\sim 0.7032)$, a high proportion of sediment relative to AOC is required to produce a subduction component sufficiently high in ${ }^{87} \mathrm{Sr} /{ }^{86} \mathrm{Sr}$ to generate the radiogenic signatures of the low-MgO group Jorullo samples, and especially those of the high$\mathrm{MgO}$ group samples. Strontium isotopes do not, however, distinguish between sediment types, as the subducting terrigenous and pelagic sediment are both comparably radiogenic in ${ }^{87} \mathrm{Sr} /{ }^{86} \mathrm{Sr}$ (Fig. 7). $\mathrm{Pb}$ isotope signatures, on the other hand, will be strongly controlled by the type of sediment involved, as the terrigenous sediment is significantly more radiogenic than the Jorullo samples, and the pelagic sediment substantially less so. Figure 10a shows that in order to reproduce the Jorullo low-Mg group sample trend in $\mathrm{Sr}-\mathrm{Pb}$ isotope space, mixing between an NMEP mantle source and fluid derived from $\geq 78 \%$ sediment (90:10 terrigenous to pelagic) and 
$\leq 22 \%$ AOC is required to produce the radiogenic $\mathrm{Sr}$ isotope signatures, and accommodate addition of $\geq 4 \%$ subduction component (i.e. $\geq 3 \%$ sediment). If the sediment component were dominated by pelagic rather than terrigenous sediment, then an even greater fraction of the subduction component would have to be sediment-derived to produce the $\mathrm{Sr}$ and $\mathrm{Pb}$ isotope signatures of the low-MgO group samples. However, in the latter scenario, $<4 \%$ subduction component (i.e. $<3 \%$ sediment) can be accommodated, which would be at odds with the minimum subduction component required to reproduce the heavy $\delta^{18} \mathrm{O}$ signatures. Furthermore, we note that the young age of the Cocos plate subducting beneath central Mexico (i.e. the close proximity of the East Pacific Rise to the continental margin), should result in limited accumulation of pelagic relative to that of terrigenous sediment on the downgoing plate, in contrast to the relative proportions observed in the single sample from the DSDP site 487 core.

The Hf-Nd isotope systematics are also particularly sensitive to the relative proportions of terrigneous and pelagic sediment, hence can provide further constraints on the composition of the subduction component (Fig. 10b, 11c). The relatively steep trend of the Jorullo samples (approximately parallel to the MORB-OIB array), combined with the strongly concave downward curvature for mixing between NMEP and subduction fluid or melt, clearly requires a sediment component that is dominated by terrigenous sediment with a minimal contribution of pelagic sediment, in agreement with the $\mathrm{Sr}-\mathrm{Pb}$ isotope systematics. Together, the $\delta^{18} \mathrm{O}$ and the $\mathrm{Sr}-\mathrm{Pb}-\mathrm{Nd}-\mathrm{Hf}$ isotope systematics of the low-MgO group Jorullo samples are well reproduced by mixing between an NMEP mantle source and $4 \%$ of a subduction component $\mathrm{SC}_{1}$ that is characterized by $\sim 80 \%$ sediment-derived fluid (90:10 terrigenous:pelagic) and $\sim 20 \%$ AOCderived fluid (Fig. 11).

For the high-MgO group samples, the situation is more complex, because it is not possible to generate a positive trend in $\mathrm{Sr}-\mathrm{Pb}$ isotope space by mixing involving unmodified NMEP mantle wedge with sediment and altered oceanic crust. However, input of a second slab component $\left(\mathrm{SC}_{2}\right)$ consisting of higher ${ }^{87} \mathrm{Sr} /{ }^{86} \mathrm{Sr}$ and ${ }^{206} \mathrm{~Pb} /{ }^{204} \mathrm{~Pb}$ to the already metasomatised mantle source of the low-MgO samples can explain the high-MgO group. In this case, a subduction component with a slightly higher fraction of terrigenous relative to pelagic sediment (95:5) compared to that of the low-MgO mantle source (90:10), but again comprising $\sim 80 \%$ sediment- and $20 \%$ slab-derived fluid, can explain the distinct trends in $\mathrm{Sr}-\mathrm{Pb}$ isotope space (Fig. 11a). Based on our modeling results, addition of $\sim 1 \%$ of $\mathrm{SC}_{2}$ to the most metasomatised part of the mantle source of the low- $\mathrm{MgO}$ group can produce the range of $\mathrm{Sr}, \mathrm{Nd}, \mathrm{Pb}, \mathrm{Hf}$ isotopic compositions of the high-MgO Jorullo group with a minimal increase in the $\delta^{18} \mathrm{O}$ values (Fig. 11).

The mixing scenario developed above based on oxygen and radiogenic isotope systematics also produces a good fit to most of the trace element data (Fig. 12). In this model, we assume an initially unmetasomatised NMEP mantle source with typical upper mantle mineralogy of 55\% olivine, $32 \%$ orthopyroxene, 10\% clinopyroxene, and 3\% garnet (e.g. Carter, 1970), and depleted mantle trace element abundances. The presence of garnet in the source region is indicated by the high $\mathrm{Dy} / \mathrm{Yb}$ (1.8 to 2) values of the Jorullo samples relative to N-MORB (Dy/Yb 1.5). The trace element patterns of the low-MgO group samples can be reproduced by $\sim 9 \%$ partial melting of the $\mathrm{SC}_{1}$-metasomatised NMEP mantle source. However, as shown in Fig 12a, this model (dictated by the oxygen isotope requirement of $\geq 4 \%$ subduction fluid addition) predicts higher $\mathrm{Cs}, \mathrm{Rb}$, and $\mathrm{Pb}$ concentrations than observed. Likewise, the three-component mixing model involving NMEP and composite subduction components $\mathrm{SC}_{1}$ and $\mathrm{SC}_{2}$ also produces acceptable fits to most of the trace element data. In general, the trace element abundances of the high- $\mathrm{MgO}$ 
magmas can be generated by $\sim 15 \%$ partial melting of the $\mathrm{SC}_{1}$ - and $\mathrm{SC}_{2}$-metasomatised NMEP mantle (Fig.12b), although the model again predicts higher $\mathrm{Cs}, \mathrm{Rb}$, and $\mathrm{Pb}$ concentrations than observed. Similar issues for Rb (Johnson et al., 2009) and $\mathrm{Ba}$, U, and $\mathrm{Pb}$ (Gomez-Tueña, 2007) have been noted previously in other studies of the TMVB. Straub et al. (2015) recently proposed that the recycled crustal component may be controlled by subduction erosion of the upper plate, in which there are known crustal lithologies (e.g. granodiorite and biotite gneiss) with relatively low $\mathrm{Rb}, \mathrm{Ba}$, and $\mathrm{Pb}$ concentrations, although the terrigenous sediment from site DSDP 487 is also most likely derived from the crystalline basement of the Mexican margin (Plank and Langmuir, 1998).

Given the uncertainties in the experimentally determined partition coefficients, the discrepancies in $\mathrm{Cs}, \mathrm{Rb}$, and $\mathrm{Pb}$ concentrations in the present model relative to the Jorullo data could indicate that the partition coefficients $\left(\mathrm{D}^{\text {slab/fluid }}\right)$ utilized in the models are not appropriate; the Jorullo $\mathrm{Cs}$ and $\mathrm{Rb}$ data are best approximated if the $\mathrm{D}^{\text {slab/fluid }}$ is $\sim 3$-fold higher than those reported by Johnson and Plank (1999) at $2 \mathrm{GPa}$ and $700^{\circ} \mathrm{C}$. It is nevertheless notable that the three elements that exhibit significant discrepancy between the model and the Jorullo data are among those that are generally considered to be the most highly fluid mobile elements (e.g. Weaver, 1991; Tatsumi and Kogiso, 1997). Therefore, it is likely that a fraction of the sediment budget of $\mathrm{Cs}, \mathrm{Rb}$, and $\mathrm{Pb}$ would be lost during low temperature, low pressure dewatering in the forearc (e.g. Brocher et al., 2003; Schmidt and Poli, 1998).

An alternative possibility is that the assumption of $\geq 3 \%$ sediment addition in the subduction component added to the mantle wedge beneath Jorullo, based on measured heavy $\delta^{18} \mathrm{O}$ signatures in the Jorullo olivines, is incorrect. In Appendix 6 (Appendix Figs. 1 and 2) we demonstrate that a similar model, in which the NMEP mantle is fluxed by a lesser amount $(\sim 1 \%)$ of $\mathrm{SC}_{1}$ and $\mathrm{SC}_{2}$, followed by lower degrees of partial melting $(\sim 3.5 \%$ and $6 \%$, versus $9 \%$ and $15 \%$ ) can also explain the chemical and radiogenic isotopic signatures of Jorullo samples, without the discrepancies in $\mathrm{Cs}, \mathrm{Rb}$, and $\mathrm{Pb}$ concentrations. Such a model may be applicable if the $\delta^{18} \mathrm{O}$ signature of the pre-subduction mantle wedge beneath Jorullo is already isotopically heavy, as has been proposed for the Cascades. Martin et al. (2011) postulated that elevated $\delta^{18} \mathrm{O}$ values (to 6.08\%) in olivines from high magnesium olivine tholeiites and basaltic andesites from Mt. Shasta and Medicine Lake volcanoes might be attributed to a slab window that allows flow of previously enriched ancient forearc mantle into the mantle wedge beneath the Cascades (e.g. Zandt and Humphreys, 2008). Such a process could also potentially explain the elevated $\delta^{18} \mathrm{O}$ observed in the Jorullo magmas. There is evidence for the Rivera-Cocos slab tear extending behind and to the eastern edge of the MGVF (e.g. Ferrari et al., 2004), and perhaps more directly relevant, a slab tear has been proposed along the projection of the Orozco fracture zone, just to the east of Jorullo (Dougherty et al., 2012). However, Johnson et al. (2009) reported $\delta^{18} \mathrm{O}_{\text {olivine }}$ of $5.5 \%$ for the Hoya Alvarez alkaline magma, located behind the MGVF volcanic front and minimally affected by subduction processes $\left(<1.4 \% \mathrm{H}_{2} \mathrm{O}\right)$; if such mantle comprises the presubduction mantle wedge beneath Jorullo, then this argues against a significantly heavy preexisting $\delta^{18} \mathrm{O}$ signature.

We therefore favor a model in which the oxygen isotope signatures as well as the radiogenic isotope and trace element signatures of the Jorullo magmas are dominated by the current subduction, with initial dewatering of sediment (and partial loss of sediment $\mathrm{Cs}$, Rb, and $\mathrm{Pb}$ ) in the forearc, followed by continued sediment dewatering and dehydration of the AOC and mantle wedge serpentinite beneath Jorullo. We note that aspects of this model are in good agreement with those derived for the MGVF by independent means. The obtained range in 
degree of partial melting is in good agreement with the results of Johnson et al. (2009), which were based on volatile and trace element compositions of melt inclusions, and the total slab contribution to the mantle wedge $(\sim 4-5 \%)$ is broadly consistent with the water contents of Jorullo magmas (5-6\%) and other MGVF melt inclusions (Johnson et al., 2009), as well as for estimates of subduction contributions to arcs globally (e.g. Elliot et al., 1997; McCulloch and Gamble, 1991).

\subsection{Physical model \& chronology of metasomatism, magma generation, and eruption}

Based on our mixing models, we suggest that the Jorullo magmas are derived from melting of a heterogeneous mantle source produced by subduction modification of an NMEP-type mantle wedge. The origin of the mantle sources of the low and high-MgO groups can be explained by a multi-step, three component mixing process as illustrated in Fig 13. Initially, mantle that was previously melted to produce the intraplate alkaline basalts of the NMEP, was advected into the sub-arc environment by corner flow. This convecting NMEP upper mantle was then infiltrated by a $\mathrm{H}_{2} \mathrm{O}$-rich component $\left(\mathrm{SC}_{1}\right)$ derived through dehydration of the subducting Cocos plate (terrigenous sediment $>>$ pelagic sediment $>>$ AOC), which produced the mantle source of the low-MgO Jorullo samples.

Influx of a second subduction component $\left(\mathrm{SC}_{2}\right)$, which differed only by a slightly higher contribution of terrigenous to pelagic sediment (95\% vs. $90 \%$ ), was subsequently added to the metasomatised source of the low- $\mathrm{MgO}$ group samples to produce the source of the high-MgO group samples. The minor difference in the relative proportions of the sediment types in $\mathrm{SC}_{1}$ versus $\mathrm{SC}_{2}$ could be attributed to heterogeneity in the sediment pile and/or to incomplete homogenization of a heterogeneous sediment-derived fluid. Alternatively, Patino et al. (2000) proposed that a horst and graben structure in the subducting plate could lead to variability in sediment proportions because the upper terrigenous unit may be scraped off a horst into an adjacent graben during subduction, resulting in a higher proportion of terrigenous sediment in the graben structure. Regardless, it is envisioned that this $\mathrm{H}_{2} \mathrm{O}$-rich $\mathrm{SC}_{2}$ component infiltrated the already metasomatised mantle, forming the mantle source for the high-MgO group. Estimates of the depth of melt extraction using the silica-activity barometer of Putirka (2008) indicates that both the high- $\mathrm{MgO}$ and low-MgO group melts were extracted from similar depths corresponding to pressures of 1.3-1.6 GPa (Appendix 7), suggesting that the mantle source region is heterogeneous on a small spatial scale, laterally and/or vertically, beneath Jorullo.

The temporal-compositional variation identified within the prolonged monogenetic eruption of Jorullo, recorded most robustly by the tephra sequence, can therefore be attributed in part to changes in mantle source over time and can be summarized as follows. Melting of the NMEP mantle metasomatised by both $\mathrm{SC}_{1}$ and $\mathrm{SC}_{2}$, which was presumably the more metasomatised and water-rich mantle wedge region, produced the early high-MgO group. Previous studies (Luhr and Carmichael, 1985; Johnson et al., 2008) suggest that the early melts rose from depth and stalled at the lower crust-upper mantle boundary where they underwent initial fractionation; however, based on the major and minor element data, the early erupted magmas are relatively primitive, suggesting minimal storage prior to eruption. Nevertheless, the variations in $\mathrm{MgO}$ with stratigraphic height in the tephra sequence (Fig. 3b) indicate that the high-MgO group magmas may have been produced in at least two batches, the first of which underwent minor fractionation prior to a recharge event involving a second pulse of mafic magma generation from the same mantle source. The new mapping of the Jorullo area (Guilbaud 
et al., 2011) suggests that these early lava flows were emitted from fissure vents rather than solely from the main Jorullo cone.

Evidence from major and trace element data suggest that some of the early melt underwent extensive fractionation before eruption, likely in a shallow magma chamber, and produced the very last eruptive phase at Jorullo (the amphibole-bearing sample JOR 0766). This late phase of the eruption had major and trace element characteristics of the low-MgO group, but isotopic signatures similar to those of the high-MgO group, arguing for a shared mantle source and early magma generation despite its late eruption.

Exhaustion of the more metasomatised, water-rich mantle led to melting of the less metasomatised mantle (that received only $\mathrm{SC}_{1}$ ) with time, producing the parental magmas for the low-MgO group. The late Jorullo melts rose from depth, and likely stalled in a magma chamber above or around that of JOR-0766, where they underwent extensive fractionation. Previous studies have suggested that a shallow magma chamber developed as the eruption of Jorullo progressed. The evidence for amphibole fractionation in the low-MgO group magmas suggests that the fractionation occurred in part at mid-crustal depths, but melt-inclusion volatile data suggest that pre-eruptive crystallization continued to very shallow crustal depths, possibly $<1 \mathrm{~km}$ (Johnson et al., 2008). Nevertheless, the isotopic and trace element data obtained in this study indicate that stalling and fractionation in a shallow magmatic plumbing system did not promote significant crustal assimilation. These low-MgO melts erupted primarily from the main Jorullo cone, as did the final stage of the eruption, which consisted of the eruption of the earlier formed JOR-0766 magma.

Together, the detailed field and geochemical studies of the complete Jorullo eruptive cycle have provided new insight into the origin of the chemical heterogeneity observed in this single monogenetic eruption. Our results suggest that the mantle is heterogeneous on a small spatial scale beneath the volcano, and that sequential tapping of this variably hydrated mantle, produced by at least two distinct slab-derived fluid fluxes, led to the production of two distinct parental magmas. Although previous models for monogenetic eruptions that become more silicic with time have invoked progressive tapping of pyroxenite-veined mantle (e.g. Reiners, 2002; Straub et al., 2011) to explain correlations between major element composition and isotopic indicators of source, our results suggest that distinct magma batches with similar initial major and trace element compositions evolved separately within a complex magmatic plumbing system. This process led to the apparently fortuitous relationship in which sequentially more evolved magmas erupted with time from a progressively less metasomatised source. Only the final eruption of JOR-0766, which links the source of the most evolved, latest erupted magma to that of the least evolved, earliest erupted magmas, allows us to distinguish between these models for compositionally zoned monogenetic eruptions.

\section{Acknowledgments}

Thanks are owed to Dave Kuentz for assistance in the field and TIMS analyses at Miami University, and to Rick Carlson for assistance with the high-precision $\mathrm{Pb}$ and $\mathrm{Hf}$ isotope measurements at DTM. This work was supported by NSF EAR grant \# 1019798 awarded to Widom and a GSA student grant awarded to Rasoazanamparany. The University of Wisconsin Madison, Geology Stable Isotope Lab. is supported by NSF-EAR-1524336 and DOE-BES-DEFG02-93ER14389 (to Valley). Field and laboratory costs of Salinas, Valdez, Guilbaud, and Siebe were defrayed from projects funded by the Consejo Nacional de Ciencia y Tecnología 
735 (CONACyT-167231 and 152294) and the Dirección General de Asuntos del Personal 736 Académico UNAM-DGAPA IN-101915 and 105615 granted to C. Siebe and M.-N. Guilbaud. 737 The inhabitants and authorities of la Huacana and Mata de Plátano are thanked for their 738 friendliness and support. 


\section{References}

Blatter, D.L., Hammersley, L., 2010. Impact of the Orozco Fracture Zone on the central Mexican Volcanic Belt. J. Volcanol. Geotherm. Res. 197, 67-84.

Blondes, M.S., Reiners, P.W., Ducea, M.N., Singer, B.S., Chesley, J., 2008. Temporal compositional trends over short and long time-scales in basalts of the Big Pine Volcanic Field, California. Earth Planet. Sci. Lett. 269, 140-154.

Blundy, J., Wood, B., 2003. Partitioning of trace elements between crystals and melts. Earth Planet. Sci. Lett. 210, 383-397.

Brocher,T. M., Parsons,T., Trehu, A. M., Snelson, C. M., Fisher, M. A., 2003. Seismic evidence for widespread serpentinized forearc upper mantle along the Cascadia margin. Geology 31, 267270.

Cai, Y., LaGatta, A., Goldstein, S.L., Langmuir, C.H., Gómez-Tuena, A., Pozzo, A.L.M., Carrasco-Nuñez, G., 2014. Hafnium isotope evidence for slab melt contributions in the Central Mexican Volcanic Belt and implications for slab melting in hot and cold slab arcs. Chem. Geol. 377, 45-55.

Carter, J.L., 1970. Mineralogy and chemistry of the Earth's upper mantle based on the partial fusion-partial crystallization model. Bull. Geol. Soc. Am. 81, 2021-2034.

Chesley J., Ruiz J., Righter K., Ferrari, L., Gómez-Tuena, A., 2002. Source contamination versus assimilation: an example from the Trans-Mexican Volcanic Arc. Earth Planet. Sci. Lett. 195, 211-221.

Connelly, J.N., Ulfbeck, D.G., Thrane, K., Bizzarro, M., Housh, T., 2006. A method for purifying $\mathrm{Lu}$ and $\mathrm{Hf}$ for analyses by MC-ICP-MS using TODGA resin. Chem. Geol. 233, 126136.

Connor, C.B., Conway, F.M., 2000. Basaltic volcanic fields. In: Sigurdsson, H. (Ed.), Encyclopedia of Volcanoes. Academic Press, New York, pp. 331-343.

Davidson, J. P., Turner, S., Handley, H., Macpherson, C. Dosseto, A., 2007. Amphibole 'sponge' in arc crust? Geology 35, 787-790.

Dougherty, S.L., Clayton, R.W., Helmberger, D.V., 2012. Seismic structure in central Mexico: implications for fragmentation of the subducted Cocos plate. J. Geophy. Res. 117, B09316, doi: 10.1029/2012JB009528.

Eiler, J.M., Schiano, P., Valley, J.W., Kita., Stolper, E.M., 2001. Oxygen-isotope and trace element constraints on the origins of silica-rich melts in the subarc mantle. Geochem. Geophys. Geosyst., 8, 9, doi:10.1029/2006GC001503. 
Elliot, T., Plank, T., Zindler, A., White, W., Bourdon B., 1997. Element transport from subducted slab to juvenile crust at the Mariana Arc. J. Geophys. Res. 102, 14991-15019.

Ferrari, L., López-Martínez, M., Aguirre-Díaz, G., Carrasco-Núñez, G., 1999. Space-time patterns of Cenozoic arc volcanism in central Mexico: From the Sierra Madre Occidental to the Mexican Volcanic Belt, Geology 27, 303-306.

Ferrari, L., 2004. Slab detachment control on mafic volcanic pulse and mantle heterogeneity in central Mexico. Geology 32, 77-80.

Gadow, H., 1930. Jorullo: The history of the volcano Jorullo and the reclamation of the devastated district by animals and plants. London: Cambridge University Press. p. 101.

Gómez-Tuena, A., LaGatta, A., Langmuir, C., Goldstein, S., Ortega-Gutiérrez, F., CarrascoNúñez, G., 2003. Temporal control of subduction magmatism in the Eastern Trans-Mexican Volcanic Belt: mantle sources, slab contributions and crustal contamination. Geochem. Geophys. Geosyst. 4, 9. http://doi:10.1029/2003GC000524

Gómez-Tuena, A., Langmuir, C.H., Goldstein, S.L., Straub, S.M., Ortega-Gutiérrez, F., 2007. Geochemical Evidence for Slab Melting in the Trans-Mexican Volcanic Belt. J. Petrol. 48, 537562.

Guilbaud, M-N, Siebe, C., Salinas, S., 2009. Excursions to Paricutin and Jorullo (Michoacán), the youngest volcanoes of the Trans-Mexican Volcanic Belt, A commemorative fieldtrip on the occasion of the $250^{\text {th }}$ anniversary of Volcán Jorullo's birth on September 29, 19759; Impretei, Mexico DF, $31 \mathrm{pp}$.

Guilbaud, M-N, Siebe, C., Layer, P., Salinas, S., Castro-Govea, R., Garduño-Monroy, V-H., Le Corvec, N., 2011. Geology, geochronology, and tectonic setting of the Jorullo Volcano region, Michoacán, México. J. Volcanol. Geotherm. Res. 201, 97-112.

Hart, S., 1984. A large-scale isotope anomaly in the Southern Hemisphere mantle, Nature 309, $753-757$.

Hasenaka, T., Carmichael, I.S.E., 1985. The cinder cones of Michoacan-Guanajuato, central Mexico: their age, volume and distribution, and magma discharge rate. J. Volcanol. Geotherm. Res. 25, 105-124.

Hofmann, A. W., Jochum, K. P., Seufert, M., White, W. M., 1986. Nb and Pb in oceanic basalts: New constraints on mantle evolution, Earth Planet. Sci. Lett. 79, 33-45.

Johnson, E.R., Wallace, P.J., Cashman, K.V., Delgado-Granados, H., Kent, A.J.R., 2008. Magmatic volatile contents and degassing induced crystallization at Volcán Jorullo, Mexico: Implications for melt evolution and the plumbing systems of monogenetic volcanoes. Earth Planet. Sci. Lett. 269, 477-486. 
Johnson, E.R., Wallace, P.J., Granados, H.D., Manea, V.C., Kent, A.J.R., Bindeman, I.N., Donegan, C.S., 2009. Subduction-related volatile recycling and magma generation beneath central Mexico: insights from melt inclusions, oxygen isotopes and geodynamic models. J. Petrol. 50, 1729-1764.

Johnson, M.C., Plank, T., 1999. Dehydration and melting experiments constrain the fate of subducted sediments. Geochem. Geophys. Geosyst. 1, 1999 GC000014.

Kessel, R., Schmidt, M.W., Ulmer, P., Pettke, T., 2005. Trace element signature of subductionzone fluids, melts and supercritical liquids at 120-180 km depth. Nature 437, 724-727.

Kim, Y., Miller, M.S., Pearce, F., Clayton, R.W., 2012 Seismic imaging of the Cocos plate subduction zone system in central Mexico. Geochem. Geophys. Geosyst. 13, 7, doi:10.1029/2012GC004033

Kolodny, Y., Epstein, S., 1976. Stable isotope geochemistry of deep sea cherts. Geochim. Cosmochim. Acta 40, 1195-1209.

LaGatta, A.B, 2003. Arc Magma Genesis in the Eastern Mexican Volcanic Belt. PhD thesis, Columbia University, New York.

Lassiter, J., Luhr, J., 2001. Osmium abundance and isotope variations in mafic Mexican volcanic rocks: Evidence for crustal contamination and constraints on the geochemical behavior of osmium during partial melting and fractional crystallization. Geochem. Geophys. Geosyst. 2 (2000GC000116)

Luhr, J., Carmichael, I., 1985. Jorullo Volcano, Michoacán, Mexico (1759-1774): the earliest stages of fractionation in calc-alkaline magmas. Contrib. Mineral. Petrol. 90, 142-161.

Luhr, J., 1997. Extensional tectonics and the diverse primitive volcanic rocks in the western Mexican Volcanic Belt. Can. Mineral. 35, 473-500.

Luhr, J.F., Kimberly, P., Siebert, L., Aranda-Gómez, J.J., Housh, T.B., Kysar Mattietti, G., 2006. México's Quaternary volcanic rocks: insights from the MEXPET petrological and geochemical database. Geol. Soc. Am. Spec. Pap. 402, 1-44.

Manea, V.C., Manea, M., 2010. Flat-slab thermal structure and evolution beneath Central Mexico. Pure Appl. Geophys. 168, 1475-1487.

Márquez, A., Oyarzún, R., Doblás, M., Verma, S.P., 1999. Alkalic (ocean-island basalt type) and calc-alkalic volcanism in the Mexican volcanic belt: A case for plume-related magmatism and propagating rifting at an active margin? Geology 27, 51-54. 
Martin, E., Bindeman, I.N., Grove, T.L., 2011. The origin of high-Mg magmas in Mt Shasta and Medicine Lake volcanoes, Cascade Arc (California): higher and lower than mantle oxygen isotope signatures attributed to current and past subduction. Contrib. Mineral. Petrol. 162, 945960.

Mattey, D., Lowry, D., Macpherson, C., 1994. Oxygen isotope composition of mantle peridotite, Earth Planet. Sci. Lett. 128, 231-241.

McCulloch, M.T., Gamble, J.A., 1991. Geochemical and geodynamical constraints on subduction zone magmatism. Earth Planet. Sci. Lett. 102, 358-374.

Meisel, T., Walker, R.J., Morgan, J.W., 1996. The osmium isotopic composition of the primitive upper mantle. Nature 383, 517-520.

Muehlenbachs, K., 1986. Alteration of the oceanic crust and the ${ }^{18} \mathrm{O}$ history of seawater. In: Valley, J. W., Taylor, H. P. \& O’Neil, J. R. (eds) Stable Isotopes in High Temperature

Geological Processes, Vol. 16. Washington, DC: Mineralogical Society of America, 425-444

Nägler, Th.F., Frei, R., 1997. "Plug in” Os distillation. Schweiz. Mineral. Petrogr. Mitt. 77, 123127.

Nier, A.O., 1950. A redetermination of the relative abundances of the isotopes of carbon, nitrogen, oxygen, argon and potassium. Phys. Rev. 77, 789-793.

Pardo, M., Suárez, G., 1995. Shape of the subducted Rivera and Cocos plate in southern Mexico: Seismic and tectonic implications. J. Geophys. Res. 100, 12357-12373.

Patino, L.C., Carr, M.J., Feigensen, M.D., 2000. Local and regional variations in Central American arc lavas controlled by variations in subducted sediment input. Contrib. Mineral. Petrol. 138, 265-283.

Pérez-Campos, X., Kim, Y., Husker, A., Davis, P. M. , Clayton, R. W., Iglesias, A., Pacheco, J. F. , Singh, S. K., Manea, V. C., Gurnis, M., 2008. Horizontal subduction and truncation of the Cocos Plate beneath central Mexico. Geophys. Res. Lett. 35, L18303, doi:10.1029/2008GL035127.

Petrone, C.M., Francalanci, L., Carlson, R.W., Ferrari, L., Conticelli, S., 2003. Unusual coexistence of subduction-related and intraplate-type magmatism: $\mathrm{Sr}, \mathrm{Nd}$ and $\mathrm{Pb}$ isotope and trace element data from the magmatism of the San Perdo-Ceboruco graben (Nayarit Mexico). Chem. Geol. 193, 1-24.

Plank, T., Langmuir, C.H., 1998. The chemical composition of subducting sediment and its consequences for the crust and mantle. Chem. Geol. 145, 325-394.

Putirka, K.D., 2008. Thermometers and barometers for volcanic systems. Rev. Mineral. Geochem. 69, 61-120. 
Reiners, P.W., 2002.Temporal-compositional trends in intraplate basalt eruptions: implications for mantle heterogeneity and melting processes. Geochem. Geophys. Geosyst. 3, doi:10.1029/2001GC000250.

Roeder, P. E., Emslie, R. F., 1970. Olivine-liquid equilibrium. Contrib. Mineral. Petrol. 29, 275289.

Romick, J. D., Kay, S. M., Kay, R.W., 1992. The influence of amphibole fractionation on the evolution of calc-alkaline andesite and dacite tephra from the central Aleutians, Alaska. Contrib. Mineral. Petrol. 112, 101-118.

Rowland, S. K., Jurado-Chichay, Z., Ernst, G., Walker, G. P. L., 2009. Pyroclastic deposits and lava flows from the 1759-1774 eruption of El Jorullo, Mexico: aspects of violent Strombolian' activity and comparison with Paricutín. In: Thordarson T., Self S., Larsen G., Rowland SK, Hoskuldsson A. (Eds.), Studies in Volcanology, Special Publication of IAVCEI, 2, 105-128.

Roy-Barman, M., 1993. Mesure du raport ${ }^{187} \mathrm{Os} /{ }^{188}$ Os dans les basalts et les peridotites: contribution a la systematique ${ }^{187} \mathrm{Re}-{ }^{188} \mathrm{Os}$ dans le manteau, PhD thesis, University de Paris.

Roy-Barman, M., Allègre, C.J., 1995. ${ }^{187} \mathrm{Os} /{ }^{186} \mathrm{Os}$ in oceanic island basalts: tracing oceanic crust recycling in the mantle. Earth Planet. Sci. Lett. 129, 145-161.

Schaaf, P., Heinrich, W., Besch, T., 1994. Composition and Sm-Nd isotopic data of the lower crust beneath San-Luis-Potosi, Central Mexico - evidence from a granulite facies xenolith suite. Chem. Geol. 118, 63-84.

Siebe, C., Rodríguez-Lara, V., Schaaf, P., Abrams, M., 2004. Geochemistry, Sr-Nd isotope composition, and tectonic setting of Holocene Pelado, Guespalapa and Chichinautzin scoria cones, south of Mexico City. J. Volcanol. Geoth. Res. 130, 197-226.

Shirey, S.B., Walker, R.J., 1995. Carius tube digestion for low-blank rhenium-osmium analysis, Anal. Chem. 67, 2136-2141.

Schmidt, M.W., Poli, S., 1998. Experimentally based water budgets for dehydrating slabs and consequences for arc magma generation. Earth Planet. Sci. Lett. 163, 361-379.

Snow, J.E., Reisberg, L., 1995. Os isotopic systematics of the MORB mantle: results from 1062 altered abyssal peridotites. Earth Planet. Sci. Lett. 133, 411-421.

Snyder, D.C., 2005. Processes and time scales of differentiation in silicic magma chambers: chemical and isotopic investigations. (PhD dissertation), Miami University (227p).

Staudigel, H., Davies, G. R., Hart, S. R., Marchant, K. M., Smith, B. M., 1995. Large scale isotopic $\mathrm{Sr}, \mathrm{Nd}$ and $\mathrm{O}$ isotopic anatomy of altered oceanic crust: DSDP/ODP sites 417/418. Earth Planet. Sci. Lett. 130, 169-185. 
Straub, S. M., Gómez-Tuena, A., Zellmer, G. F., Cai, M. Y., Goldstein, S. L., Langmuir, C. H., Espinasa-Pereña, R., 2008. Petrogenesis of alkaline arc basaltic andesites at Volcan Chichinautzin in the Central Mexican Volcanic Belt. Geochim. Cosmochim. Acta 72(12), A906.

Straub, S.M., Gómez-Tuena, A., Stuart, F.M., Zellmer, G.F., Espinasa-Pereña, R., Cai, Y., Iizuka, Y., 2011. Formation of hybrid arc andesites beneath thick continental crust. Earth Planet. Sci. Lett. 303, 337-347.

Straub , S.M., Gómez-Tuena, A., Zellmer, G.F., Espinasa-Pereña, R., Stuart, F.M., Langmuir, C.H., Martin-del Pozzo, A.L., Mesko, G.T., 2012. The processes of melt differentiation in arc volcanic rock: Insights from OIB-type arc magmas in the Central Mexican Volcanic Belt. J. Petrol. 54, 665-701.

Straub, S.M., Gómez-Tuena, A., Bindeman, I.N., Bolge, L.L., Brandl, P.A., Espinasa-Pereña, R., Solari, L., Stuart, F.M., Vannucchi, P., Zellmer, G.F., 2015. Crustal recycling by subduction erosion in the central Mexican Volcanic Belt. Geochim. Cosmochim. Acta 166, 29-52.

Sun, S.S., McDonough, W.F., 1989. Chemical and isotopic systematics of oceanic basalts: implications for mantle composition and processes, Magmatism in the ocean basins. Geol. Soc. London Spe. Publ. 42. 313-345.

Tatsumi, Y., Kogiso, T., 1997. Trace element transport during dehydration processes in the subducted oceanic crust: 2 . Origin of chemical and physical characteristics in arc magmatism, Earth Planet. Sci. Lett. 148, 207-221.

Valley, J. W., Kitchen, N., Kohn, M. J., Niendorff, C. R., Spicuzza, M. J., 1995. UWG-2, a garnet standard for oxygen isotope ratios: Strategies for high precision and accuracy by laser fluorination. Geochim. Cosmochim. Acta 59, 5223-5231.

Verma, S.P, 2000. Geochemistry of the subducting Cocos plate and the origin of subductionunrelated mafic volcanism at the front of the central Mexican Volcanic Belt. In DelgadoGranados H, Aguirre-Díaz G, Stock J (Eds.). Cenozoic Tectonics and Volcanism of Mexico. Geol. Soc. Amer. Spec. Pap. 334, pp. 1-28.

Verma, S., 2002. Absence of Cocos Plate subduction-related basic volcanism in southern Mexico: a unique case on Earth? Geology 30, 1095-1098.

Verma, S.P., Hasenaka, T., 2004. Sr, Nd, and Pb isotopic and trace element geochemical constraints for a veined-mantle source of magmas in the Michoacán-Guanajuato volcanic field, west-central Mexican Volcanic Belt. Geochem. J. 38, 43-65.

Wallace, P.J., Carmichael, I.S.E., 1999. Quaternary volcanism near the Valley of Mexico: implications for subduction zone magmatism and the effects of crustal thickness variations on primitive magma compositions. Contrib. Mineral. Petrol. 135, 291-314. 
1010 Weaver, B., 1991. The origin of ocean island basalt endmember compositions: trace element and 1011 isotopic constraints. Earth Planet. Sci. Lett. 104, 381-397.

1012

1013 Yu, H., 2011. Li, Hf and Os isotope systematics of Azores basalts and a new microwave

1014 digestion method for Os isotopic analysis. PhD Dissertation, Miami University, 183p.

1015

1016 Zandt, G., Humphreys, E., 2008. Toroidal mantle flow through the western US slab window.

1017 Geology 36, 295-298.

1018

1019 


\section{Figure captions}

Figure 1. Simplified regional tectonic map of the Trans-Mexican Volcanic Belt (yellow), modified after Siebe et al. (2004). The MGVF region and the location of Jorullo volcano are also indicated.

Figure 2. Geologic map of Jorullo and associated deposits. Eruptive phases are numbered from I (earliest) to VII (latest). Black outlines delineate the Jorullo lava flows; older lavas in the region are delineated as indicated in the legend. Sample locations for the lava and tephra samples are indicated as red and orange dots, respectively. The last two digits of the sample names define the lava and tephra samples (e.g. 66 represents sample JOR-0766).

Figure 3. Temporal-compositional variations in Jorullo magmas. a) Variation in $\mathrm{MgO}$ content of the lavas throughout the eruption. b) Variation in $\mathrm{MgO}$ contents of the tephra with relative stratigraphic height. Diamond symbols represent lava samples; filled circle symbols represent Jorullo tephra. Two geochemical groups can be recognized within the Jorullo samples: high$\mathrm{MgO}(>8 \mathrm{wt} \%)$ and low-MgO ( $<8 \mathrm{wt} \%)$ groups. Pink symbols represent the high-MgO group samples, and blue symbols represent the low-MgO group samples. The green diamond represents the last material erupted at Jorullo (bomb sample JOR-0766). Black crosses represent additional Jorullo samples analyzed for major and trace elements (UNAM database), the data for which are included in Appendix 3. These color and symbol designations are used for all following figures.

Figure 4. Whole rock major element vs. $\mathrm{MgO}$ (wt. \%) for the Jorullo samples analyzed in this study. Samples from Luhr and Carmichael (1985) (indicated by black dots) and the additional samples from Appendix 3 (black crosses) are shown for comparison.

Figure 5. Incompatible trace element abundances vs. $\mathrm{MgO}$ (wt \%) for the Jorullo samples analyzed in this study. Samples from Luhr and Carmichael (1985) and the additional samples from Appendix 3 are shown for comparison.

Figure 6. Trace element patterns of the Jorullo samples, normalized to normal mid-oceanic ridge basalt (N-MORB). Normalizing values are those of Sun and McDonough (1989).

Figure 7. Isotope variation diagrams for the Jorullo samples. a) Sr-Nd isotope diagram, b and c) $\mathrm{Pb}$ isotopic variation diagrams, d) Hf-Nd isotope diagram. Basement granitoids analyzed in this study (black squares) and literature data for the TMVB (open gray dots; Luhr et al., 2006) are shown for comparison. Also shown are: terrigenous sediment (blue crosses) and pelagic sediment (open orange crosses) from DSDP site 487 (LaGatta, 2003), and the average altered oceanic crust (open pink cross) from DSDP site 487 (Verma, 2000). Mantle xenoliths and lower crustal xenoliths (stars and "Y"s, respectively) are compiled from Schaaf et al. (2004). Data for East Pacific Rise (EPR) field are from "ready-to-use datasets" at PetDB (http://www.earthchem.org/petdb). 
1057 Figure 8. a) ${ }^{187} \mathrm{Os} /{ }^{188} \mathrm{Os}$ vs. Ni for Jorullo samples and other mafic samples from the MGVF 1058 (black triangles, data from Chesley et al., 2002). The mixing curves represent the AFC models of 1059 Chesley et al. (2002) and are based on the following parameters: parental magma: Os $=250 \mathrm{ppt}$, $1060 \mathrm{Ni}=300 \mathrm{ppm}$ and ${ }^{187} \mathrm{Os} /{ }^{188} \mathrm{Os}=0.135$; lower crust: $\mathrm{Os}=50 \mathrm{ppt}, \mathrm{Ni}=100 \mathrm{ppm}$ and ${ }^{187} \mathrm{Os} /{ }^{188} \mathrm{Os}=$ 1061 0.6. Bulk $\mathrm{D}_{\mathrm{Ni}}=5$. Two AFC trends are shown for bulk $\mathrm{D}_{\mathrm{Os}}$ of 10 and 20. Tick marks represent 1062 mass fraction of assimilant in $2 \%$ increments. b) $\delta^{18} \mathrm{O}$ vs. Ni contents of the Jorullo magmas.

1063 Figure 9. a) ${ }^{143} \mathrm{Nd} /{ }^{144} \mathrm{Nd}$ vs. ${ }^{87} \mathrm{Sr} /{ }^{86} \mathrm{Sr}$ and ${ }^{206} \mathrm{~Pb} /{ }^{204} \mathrm{~Pb}$ vs. ${ }^{87} \mathrm{Sr} /{ }^{86} \mathrm{Sr}$ for the Jorullo samples. Also 1064 shown are fields for the Northern Mexican Extensional Province of Luhr et al. (2006). Upper 1065 crust and lower crustal xenolith fields are compiled from Schaaf et al. (2004).

1066 Figure 10. a) ${ }^{87} \mathrm{Sr} /{ }^{86} \mathrm{Sr}$ vs. ${ }^{206} \mathrm{~Pb} /{ }^{204} \mathrm{~Pb}$ showing mixing between NMEP mantle and potential 1067 subduction components with variable mixtures of AOC and pelagic and terrigenous sediment1068 derived fluids. Mixing trajectory between terrigenous and pelagic sediment is also shown. A 1069 relatively high proportion of sediment to $\mathrm{AOC}(\sim 80: 20)$ is required to produce a subduction 1070 1071 1072 1073 1074 1075 1076 1077 1078 1079 1080 1081 1082 component with high ${ }^{87} \mathrm{Sr} /{ }^{86} \mathrm{Sr}$ required by $\mathrm{SC}_{1}$. Only the AOC-sediment mixture that is dominated by terrigenous sediment (90:10 terrigenous:pelagic) produces the required $\mathrm{Sr}$ and $\mathrm{Pb}$ isotopic signatures with $>4 \%$ subduction component added to the NMEP, as required by the heavy $\delta^{18} \mathrm{O}_{\text {olivine }}$ signatures; greater contributions of pelagic sediment dictate lower fractions of subduction component in the mixture. b) ${ }^{143} \mathrm{Nd} /{ }^{144} \mathrm{Nd}$ vs. ${ }^{176} \mathrm{Hf} /{ }^{177} \mathrm{Hf}$ diagram further illustrating the influence of terrigenous sediment in the petrogenesis of Jorullo magmas. The hypothetical NMEP mantle is represented by the green circle, and its isotopic composition was chosen to fall along an extension of the low-MgO samples data trend in $\mathrm{Sr}-\mathrm{Nd}$ and $\mathrm{Sr}-\mathrm{Pb}$ space and within the NMEP field (Figure 9). The dashed and solid curves in the diagrams indicate mixing between sediment-derived fluid (with variable proportions of terrigenous and pelagic sediment) and AOC-derived fluids, which comprise the subduction component added to the hypothetical NMEP mantle source. Tick marks show the relative proportions of the mixing components. The Jorullo samples are reproduced in $\mathrm{Hf}-\mathrm{Nd}$ isotope space with the same parameters as for $\mathrm{Sr}-\mathrm{Pb}$ isotopes.

Figure 11. Isotopic models to account for the compositional variation at Jorullo, involving an NMEP mantle wedge and two slab components $\mathrm{SC}_{1}$ and $\mathrm{SC}_{2}$. The subducted sediment and $\mathrm{AOC}$ compositions are from DSDP site 487, and the associated fluid compositions are derived using experimentally determined partition coefficients as described in the text. Model parameters are provided in Appendix 5. The stars represent the two different slab components, $\mathrm{SC}_{1}$ and $\mathrm{SC}_{2}$, that best reproduce the low-MgO and high-MgO group Jorullo magmas for a) ${ }^{206} \mathrm{~Pb} /{ }^{204} \mathrm{~Pb}$ vs. ${ }^{87} \mathrm{Sr} /{ }^{86} \mathrm{Sr}$; b) ${ }^{143} \mathrm{Nd} /{ }^{144} \mathrm{Nd}$ vs. ${ }^{87} \mathrm{Sr} /{ }^{86} \mathrm{Sr}$; c) ${ }^{176} \mathrm{Hf} /{ }^{177} \mathrm{Hf}$ vs. ${ }^{143} \mathrm{Nd} /{ }^{144} \mathrm{Nd}$; and d) $\delta^{18} \mathrm{O}$ vs. ${ }^{206} \mathrm{~Pb} /{ }^{204} \mathrm{~Pb}$. The models depicted in figures a-d represent NMEP plus $4 \%$ subduction fluid $\mathrm{SC}_{1}$ derived from $80 \%$ sediment (90:10 terrigenous:pelagic) and 20\% AOC; and a subsequent addition of $1.2 \%$ subduction fluid $\mathrm{SC}_{2}$ derived from $80 \%$ sediment (95:5 terrigenous:pelagic) and 20\% AOC. Note that $\delta^{18} \mathrm{O}$ is essentially uniform in the Jorullo samples, so figure 11d illustrates only that the scenario that reproduces the $\mathrm{Pb}$ isotopic variations in the two sample groups (fig. 11a) also produces sufficiently heavy and non-variable $\delta^{18} \mathrm{O}$. 
1096 Figure 12. Trace element modeling results showing calculated mantle source compositions for 1097 NMEP plus subduction component $\mathrm{SC} 1 \pm \mathrm{SC} 2$ (thin solid lines), and the magma derived by 1098 partial melting of the respective sources (dashed lines). a) The trace element pattern of the low$1099 \mathrm{MgO}$ group can be closely reproduced by $9 \%$ partial melting of an NMEP mantle source 1100 metasomatised by a subduction component $\left(\mathrm{SC}_{1}\right)$ as apportioned in Figure 11. b) The trace 1101 element pattern of the high-MgO group can be closely matched by $\sim 15 \%$ partial melting of an 1102 NMEP mantle source metasomatised by slab component $\mathrm{SC}_{1}$ and $\mathrm{SC}_{2}$, also as apportioned in 1103 Figure 11. Note that in both models $\mathrm{Cs}, \mathrm{Rb}$, and $\mathrm{Pb}$ are predicted by the model to be in somewhat 1104 additional explanation.

Figure 13. Schematic representation of the formation of the mantle sources of the high- and low$\mathrm{MgO}$ group samples, and the evolution with time of the high- and low-MgO magmas, leading to the documented compositional-temporal variations in the Jorullo eruption. 1) Melting of NMEP mantle metasomatised by $\mathrm{SC}_{1}$ and $\mathrm{SC}_{2}$ to produce the early high-MgO group and their eruption along the rift between the Jorullo main cone and satellite cones. The early melts rose from depth and may have ponded briefly at the lower crust-upper mantle boundary before eruption. 2) Storage of some residual high-MgO melt at a shallow crustal level to produce JOR-0766. 3) Melting of the less fertile mantle (i.e. NMEP $+\mathrm{SC}_{1}$ ) as time progressed, producing the parental low-MgO group magma. The low-MgO melts rose from depth, and likely stalled in a mid-crustal depth magma chamber above or around the chamber of JOR-0766, where amphibole fractionation occurred. The low-MgO melts erupted from the main cone. 4) The very last phase of the Jorullo eruption, represented by sample JOR-0766, erupted through the main cone. 


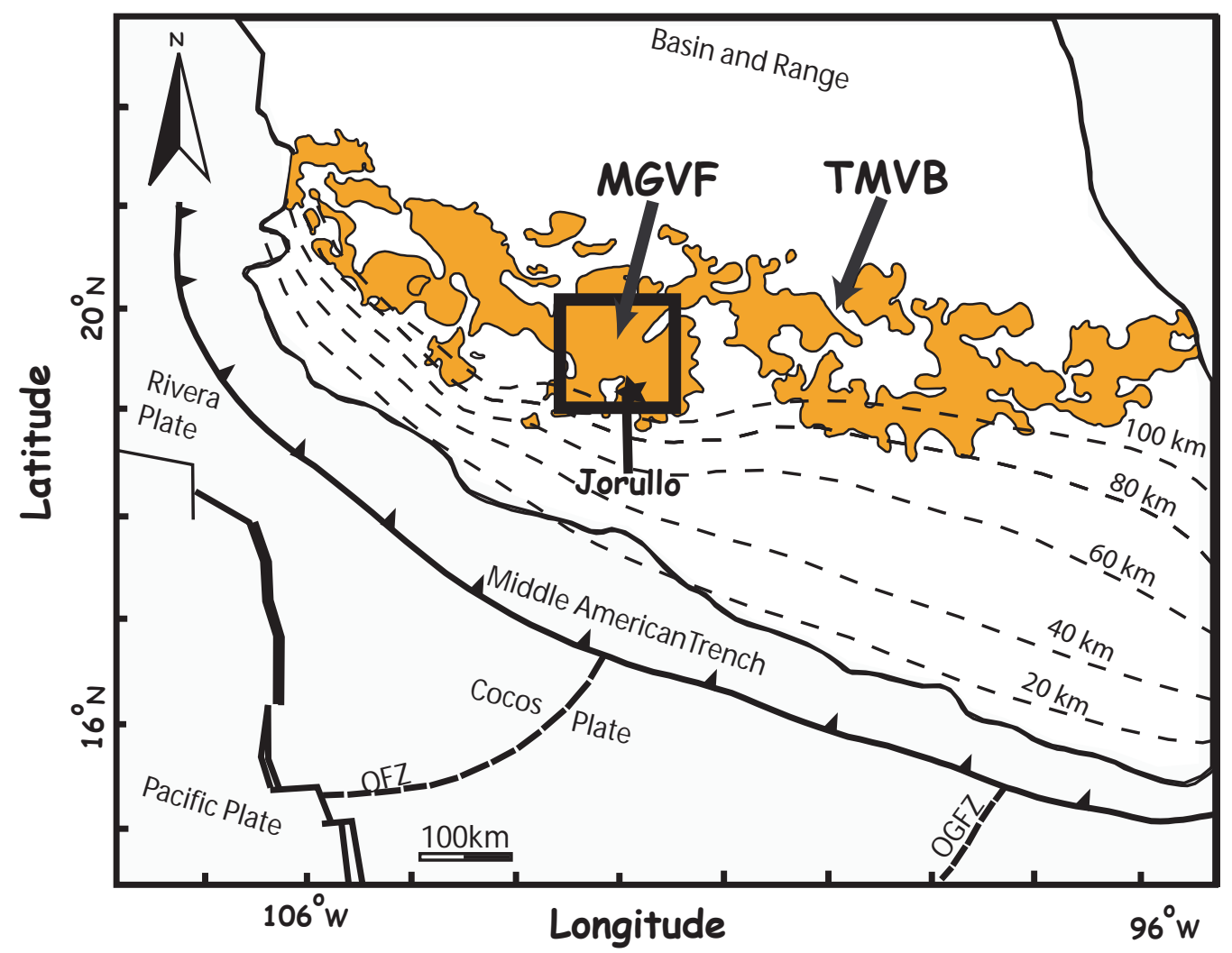




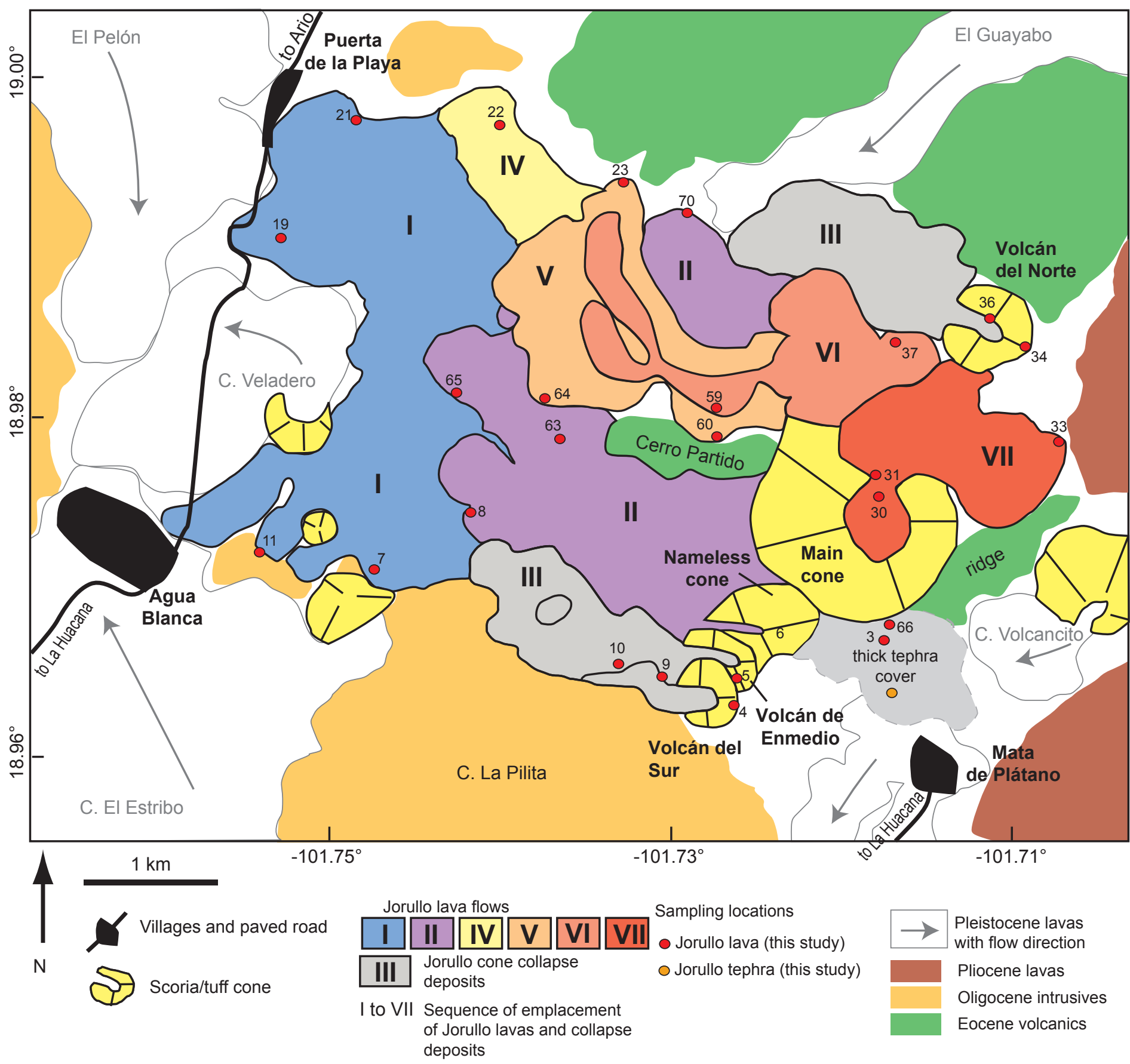



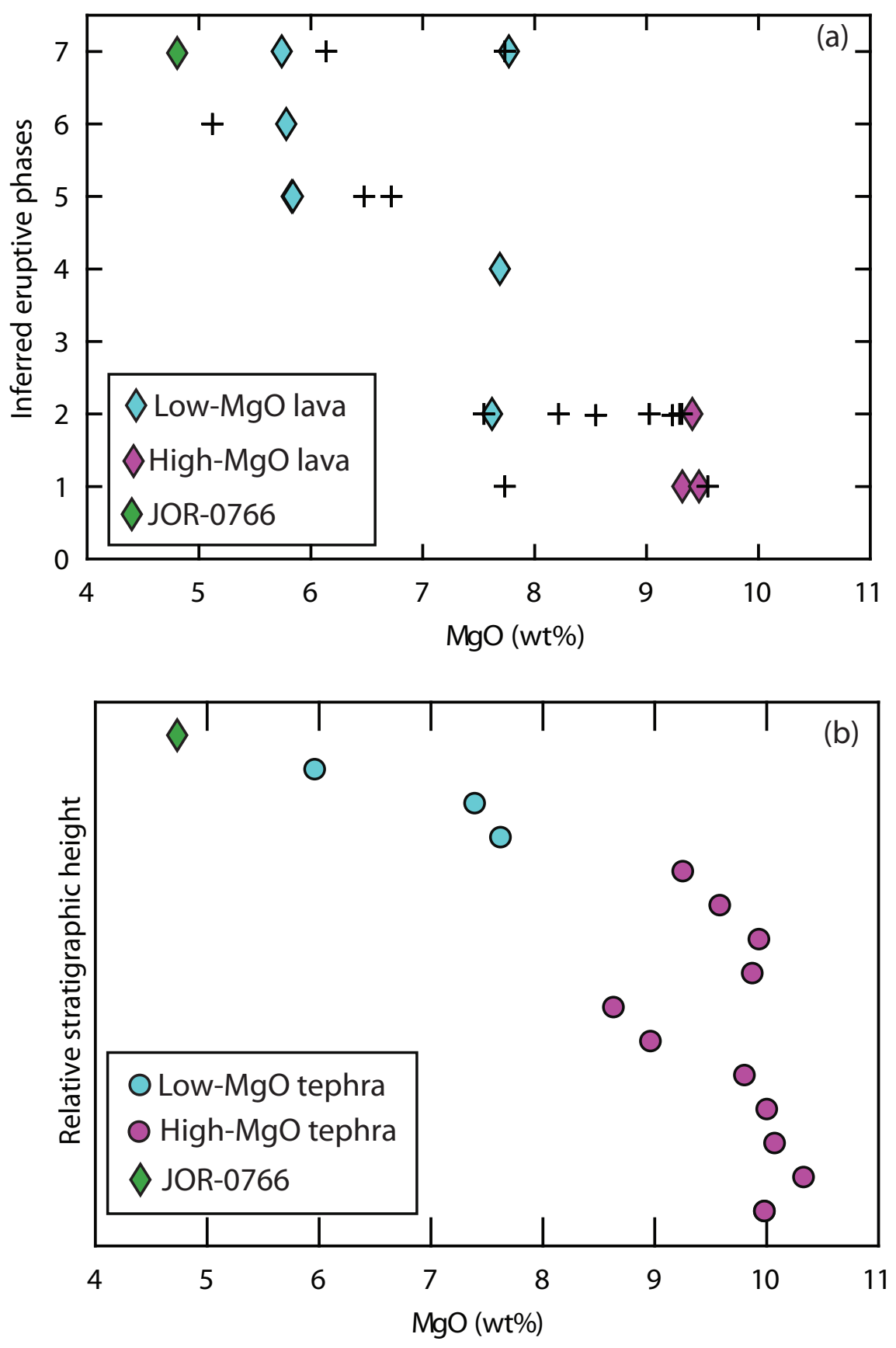
Figure 4
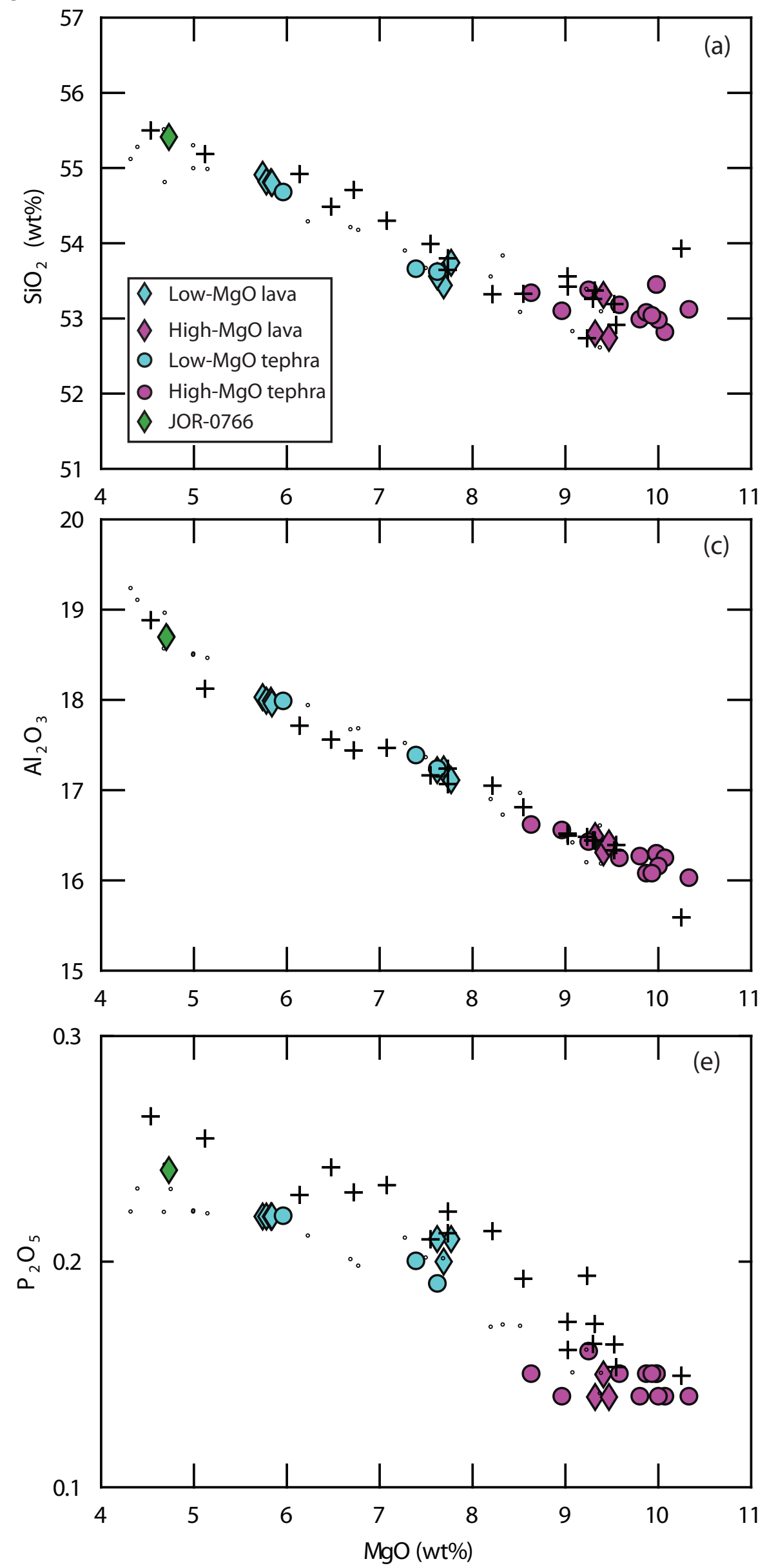
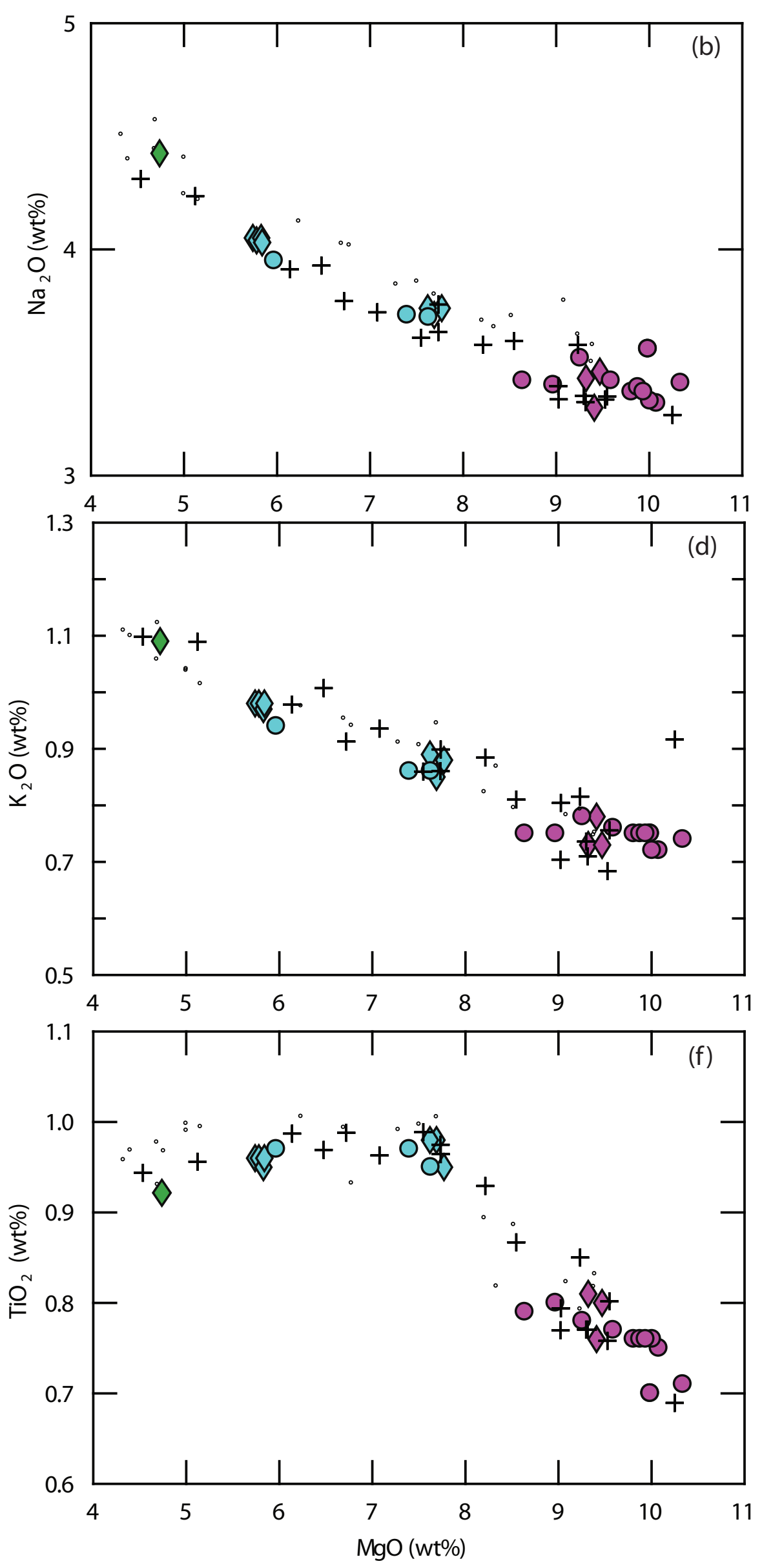

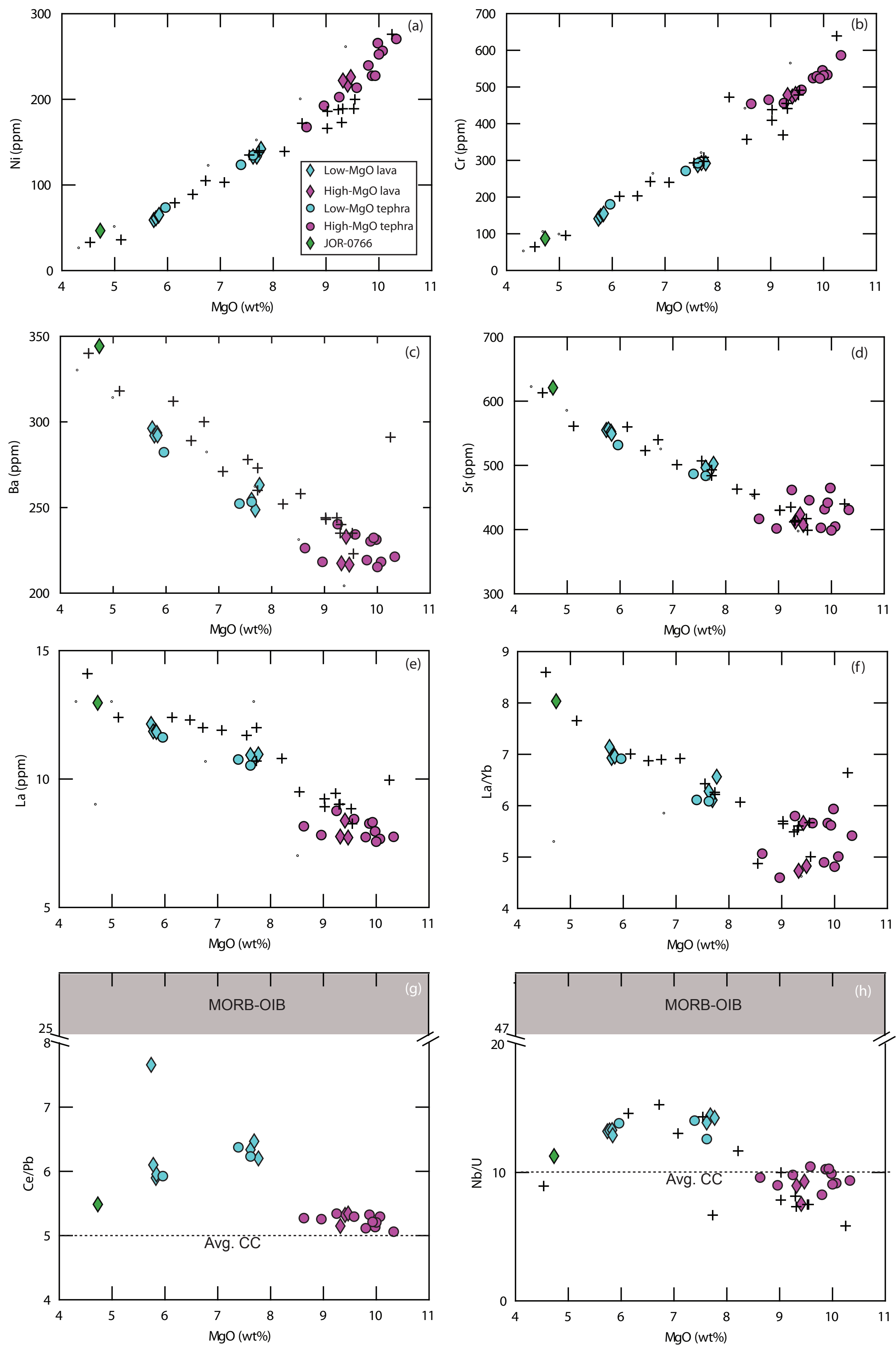
Figure 6

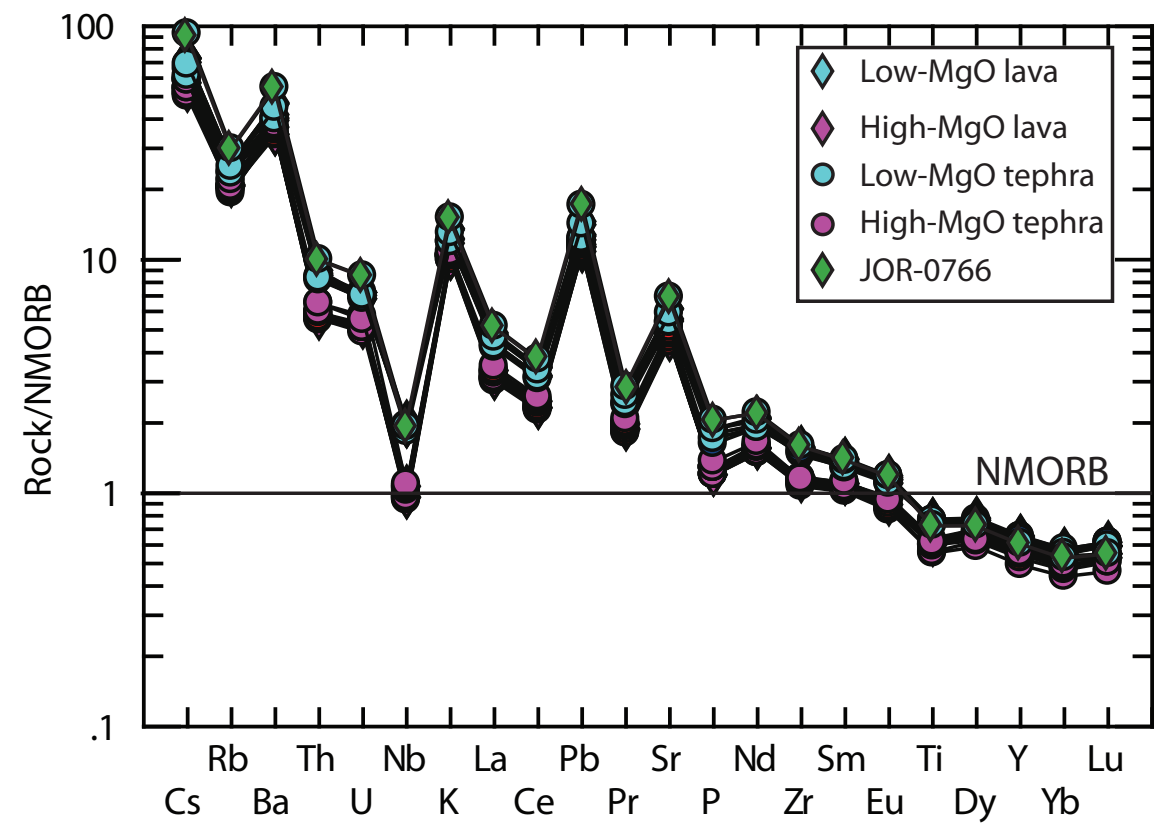

$$
\text { 要 }
$$




\section{Figure 7}
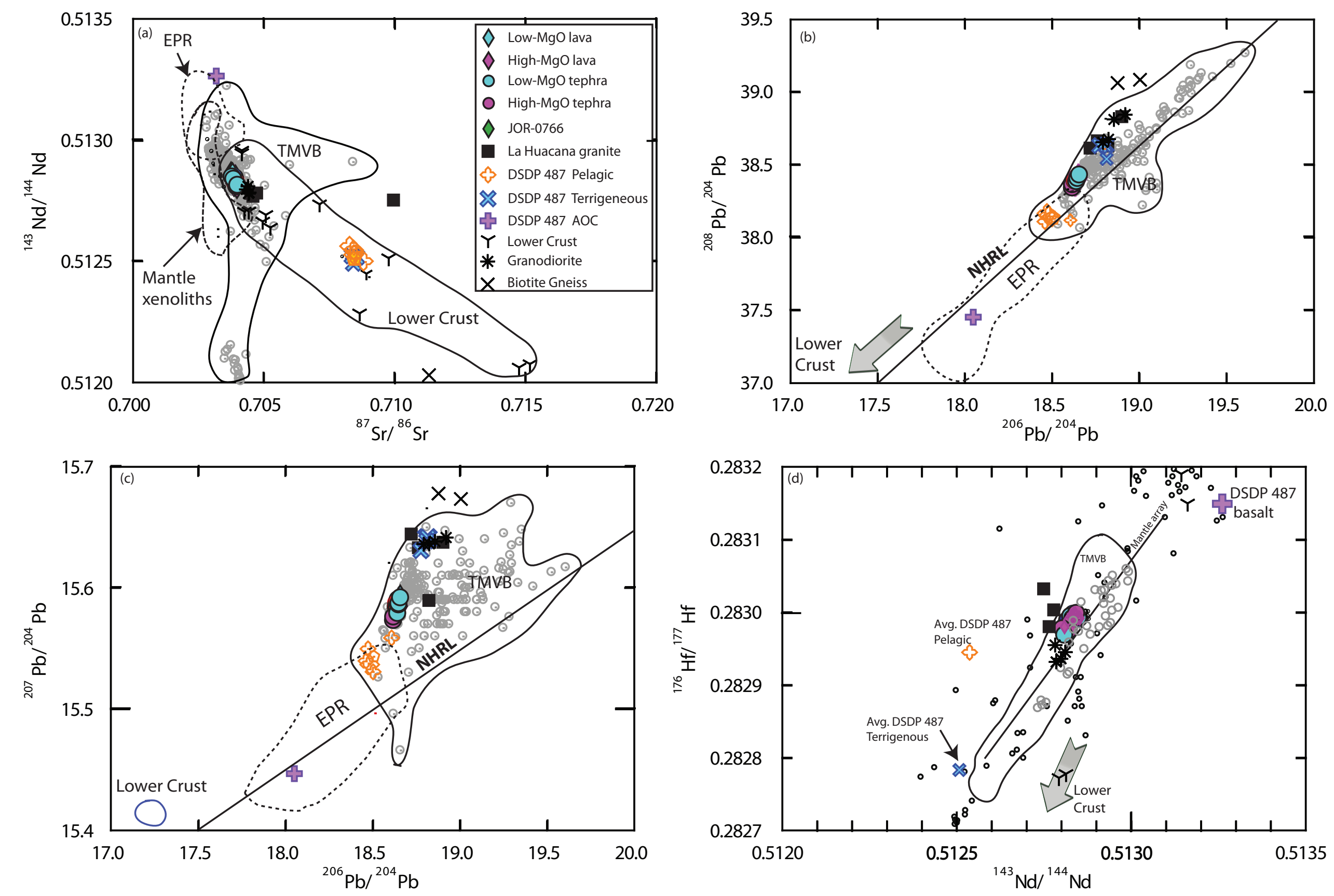

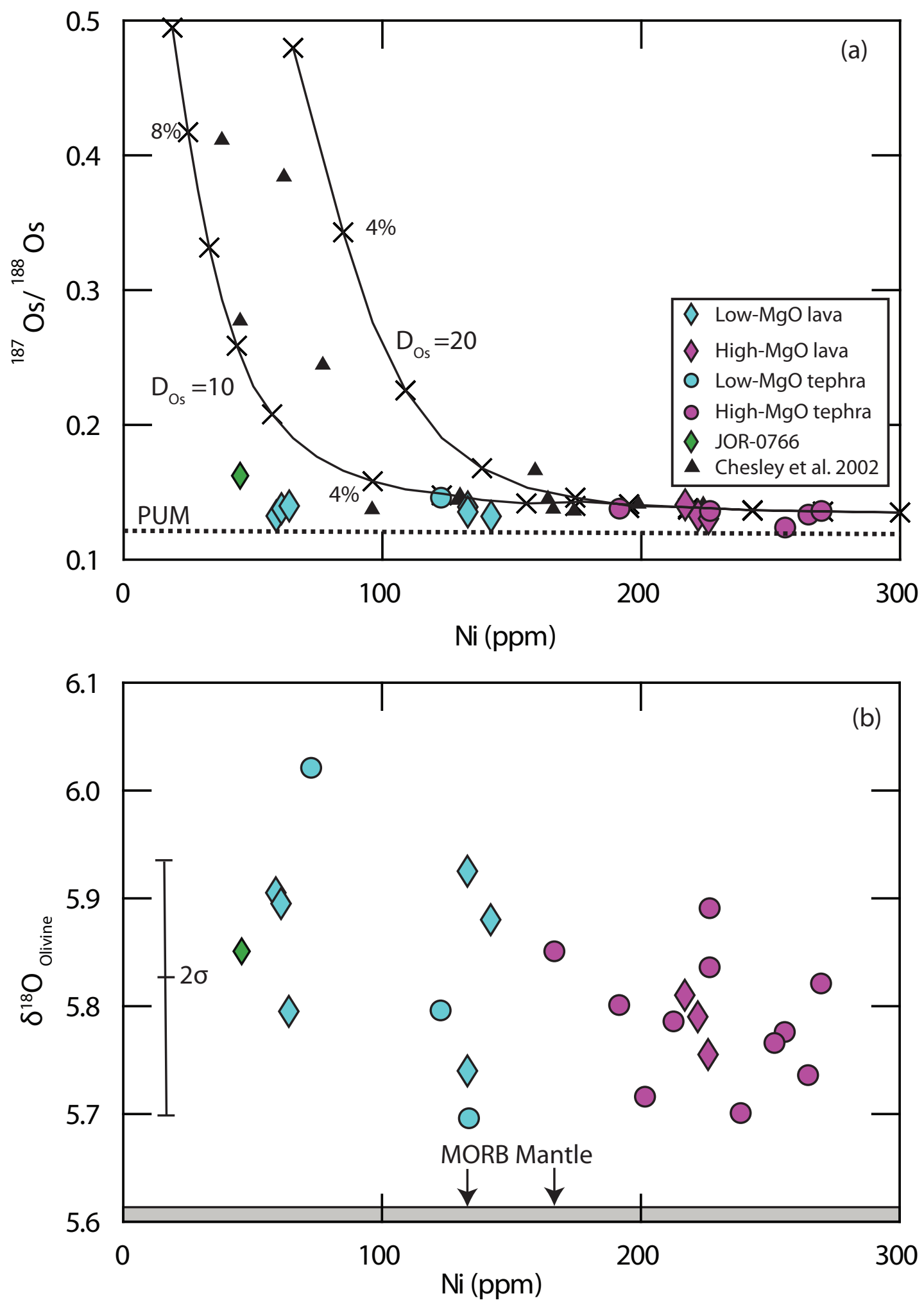
Figure 9
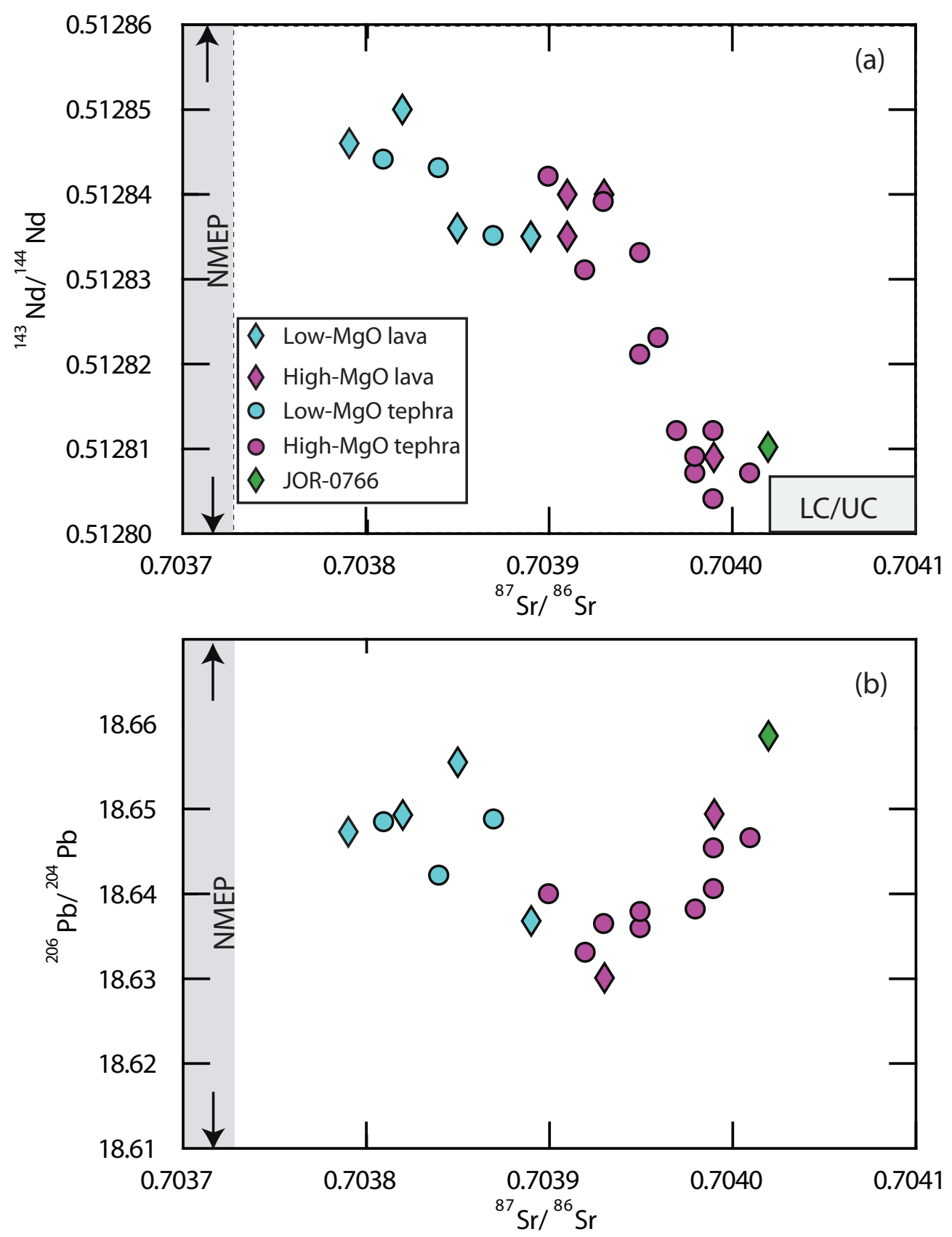

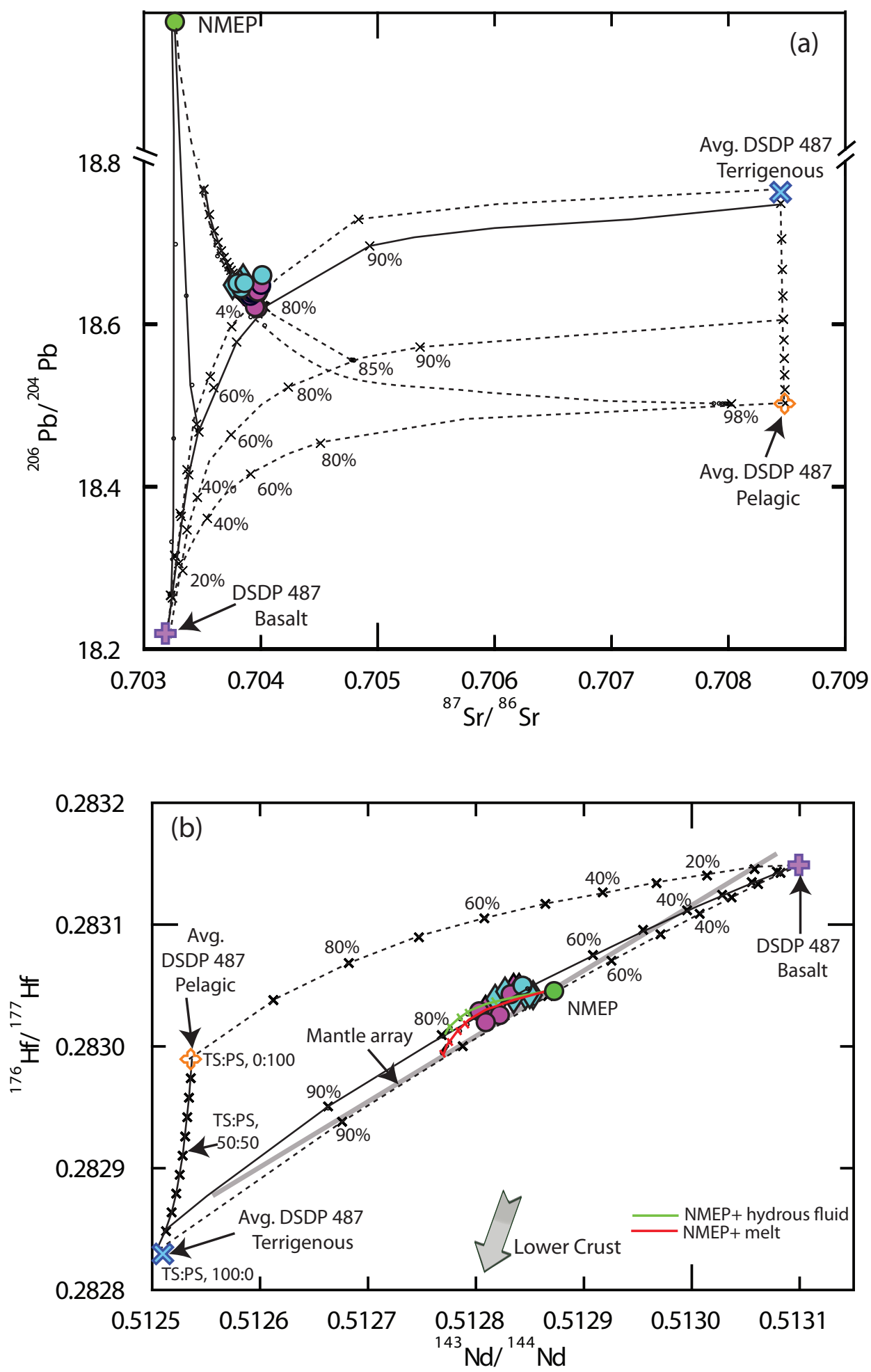
Figure 11
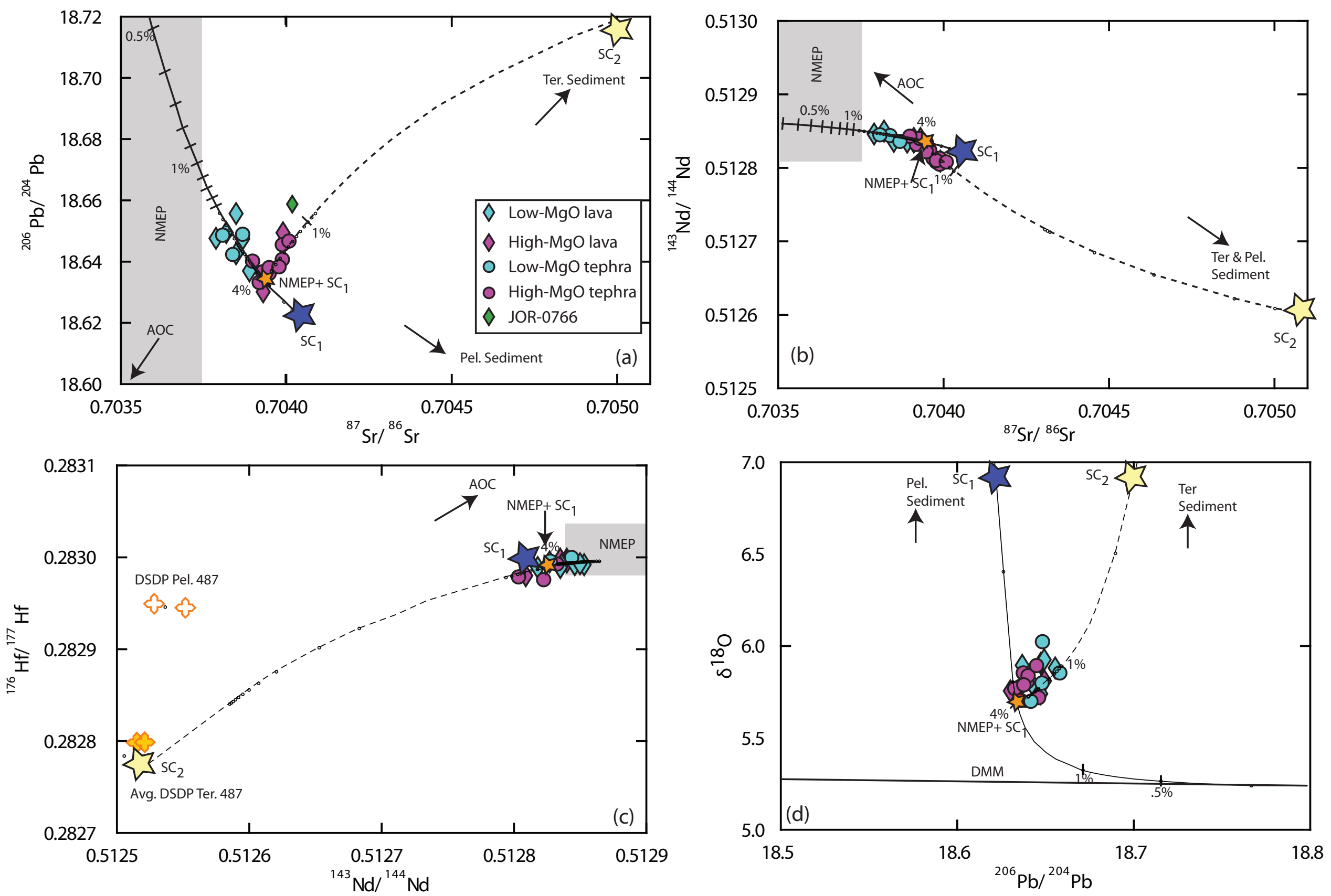

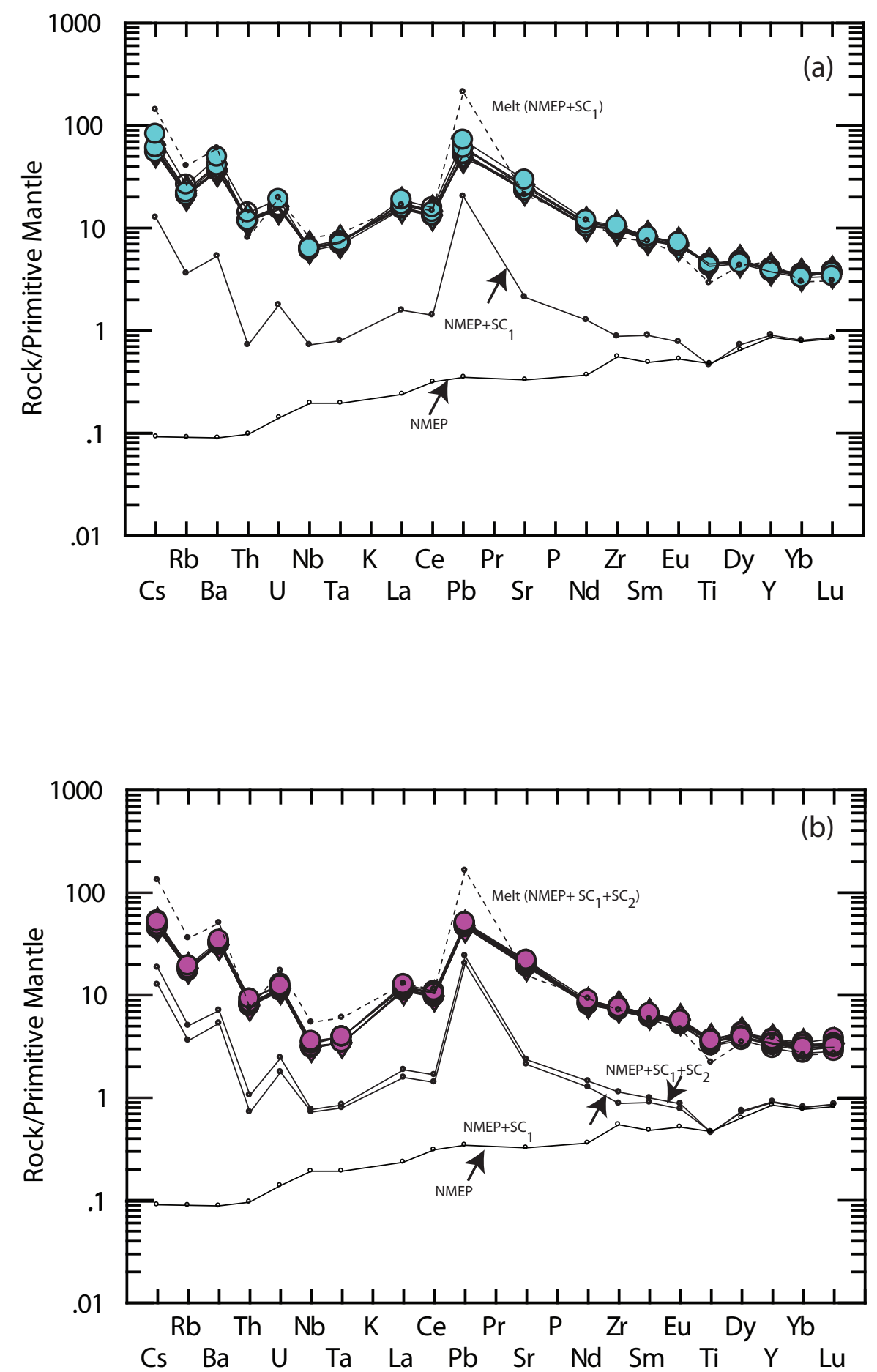
1) Melting of the NMEP+SC$+\mathrm{SC}_{2}$ to produce the early high-MgO.

Eruption of the high-MgO group magmas along fissure vents

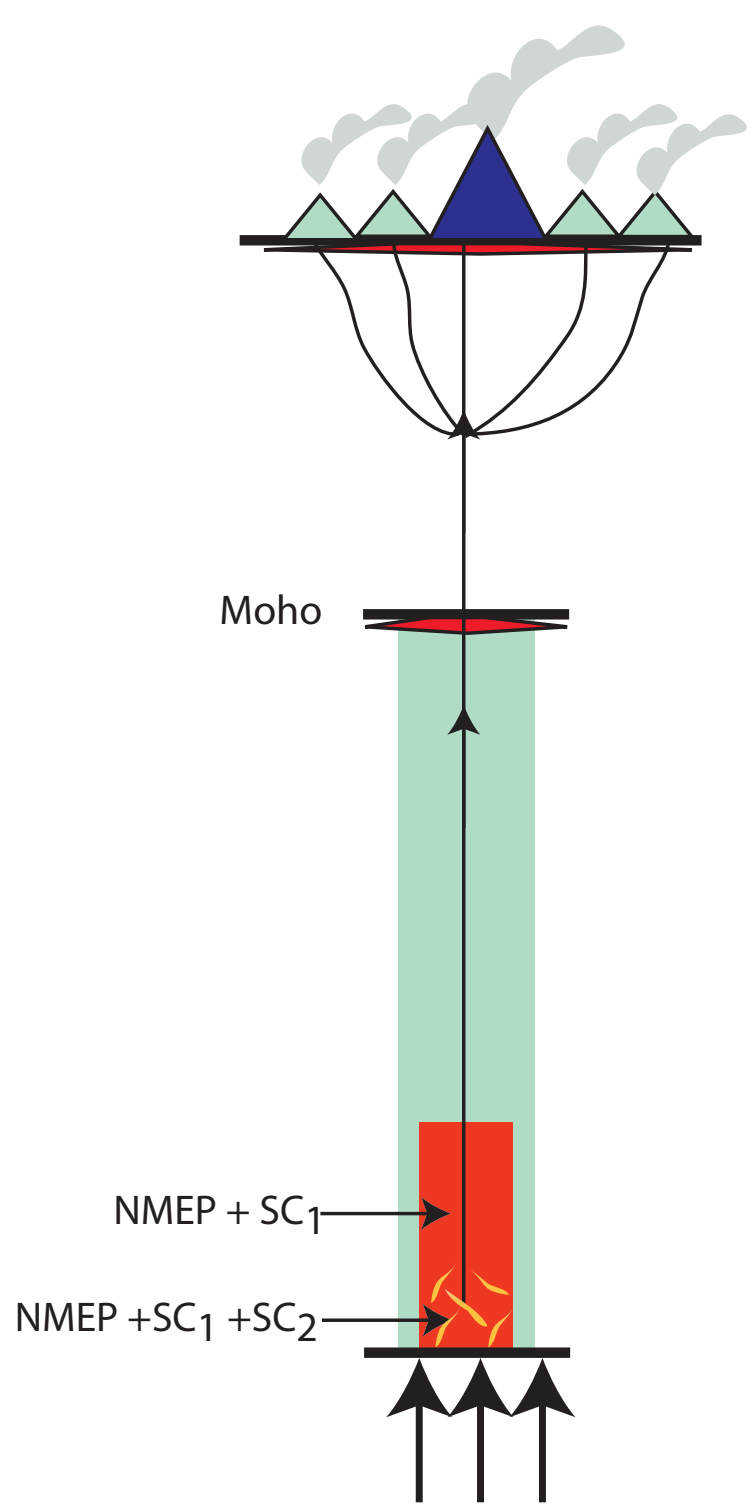

2) Development of shallow magma chamber for some residual high-MgO magma
3) Melting of the NMEP $+\mathrm{SC}_{1}$. Development of shallow magma chamber for the low-MgO melts, where they fractionated prior to eruption
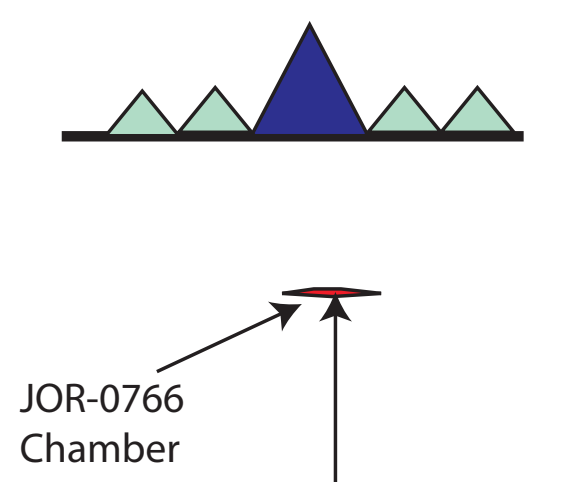

Low-MgO melts Chamber
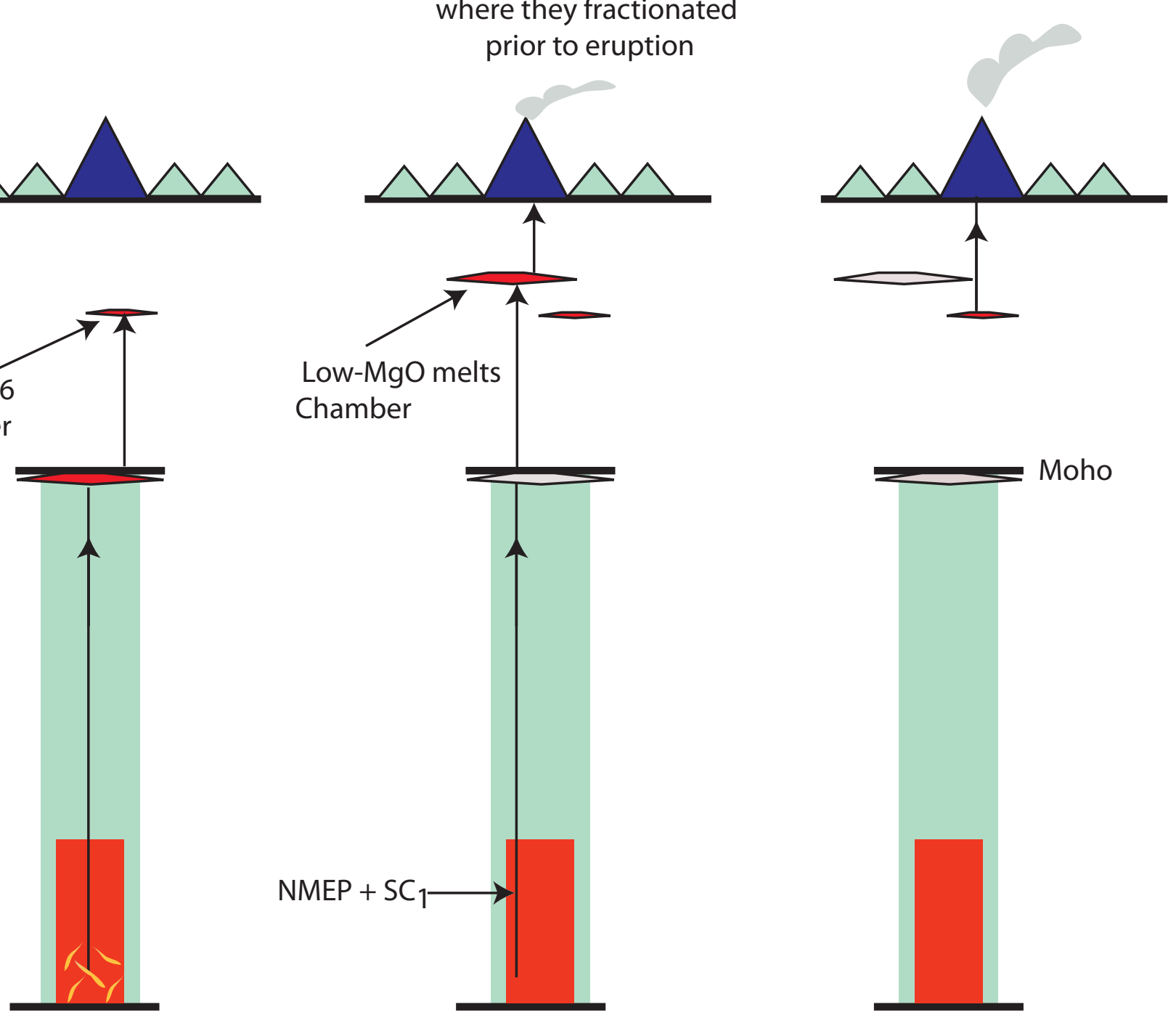

4) Final eruptive phase (JOR-0766)

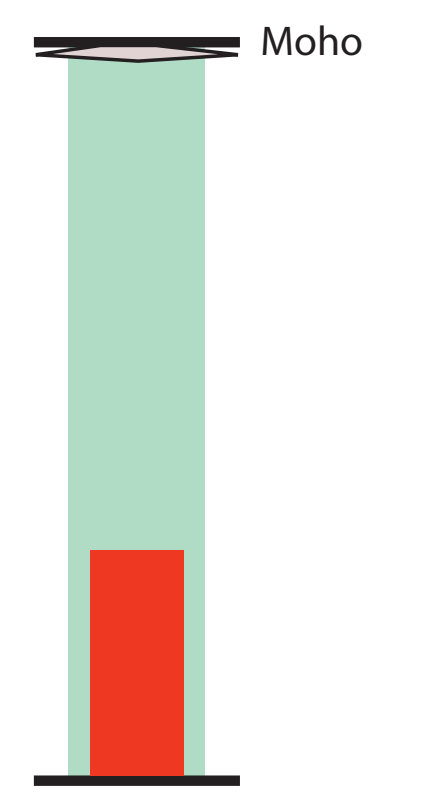


Table 1. Major (wt\%) and trace element (ppm) and isotopic data

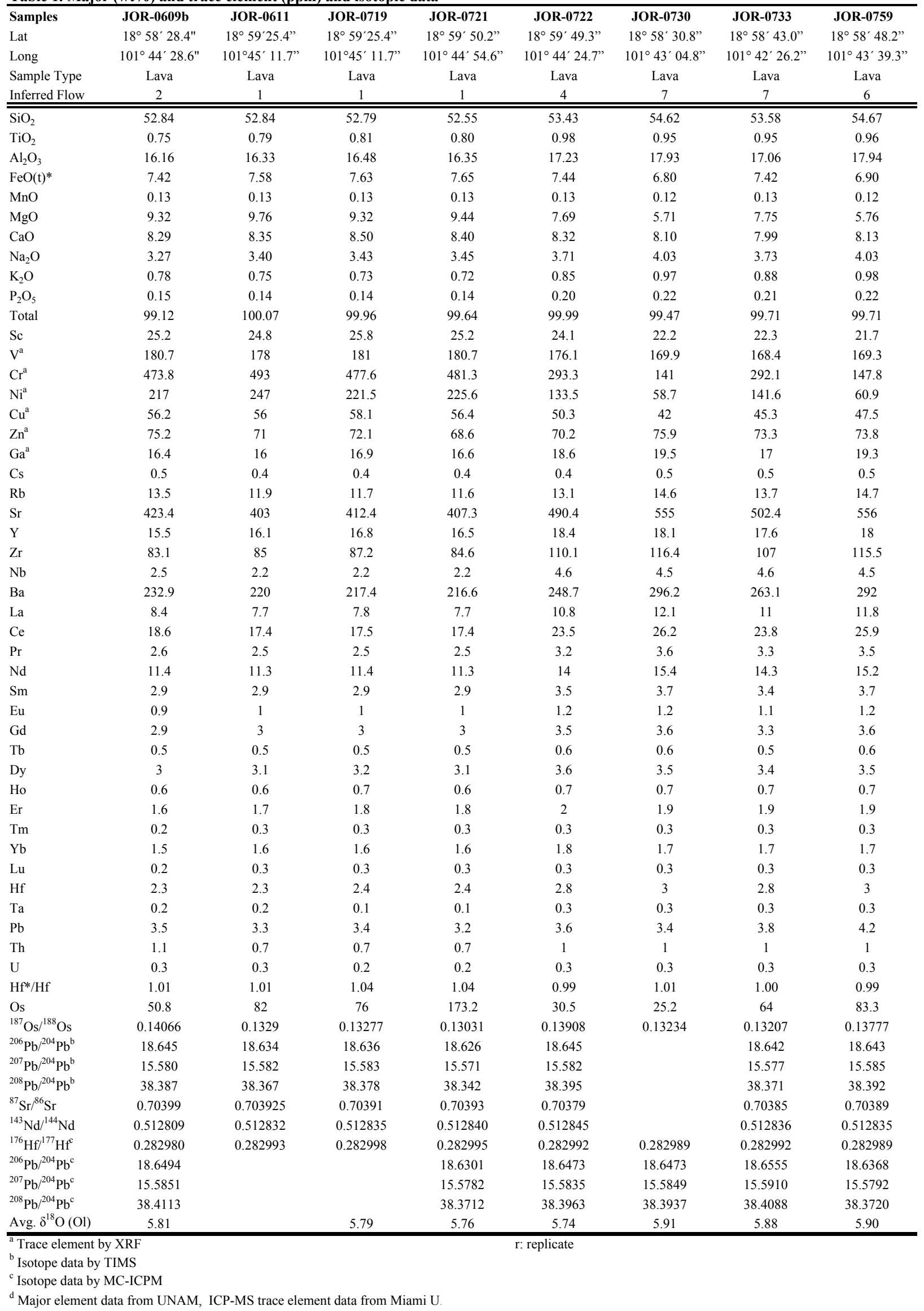


Table 1 (continued)

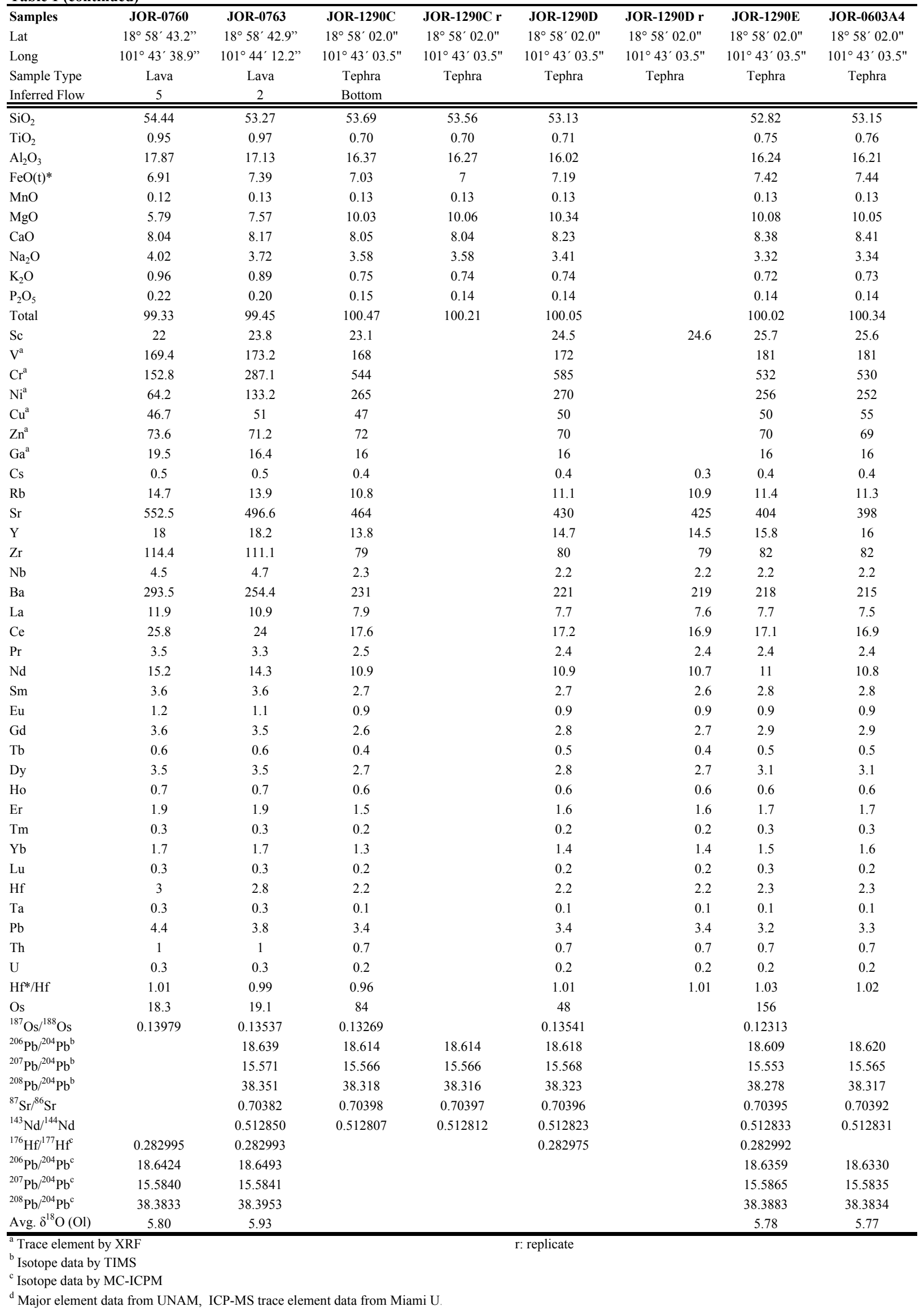


Table 1 (continued)

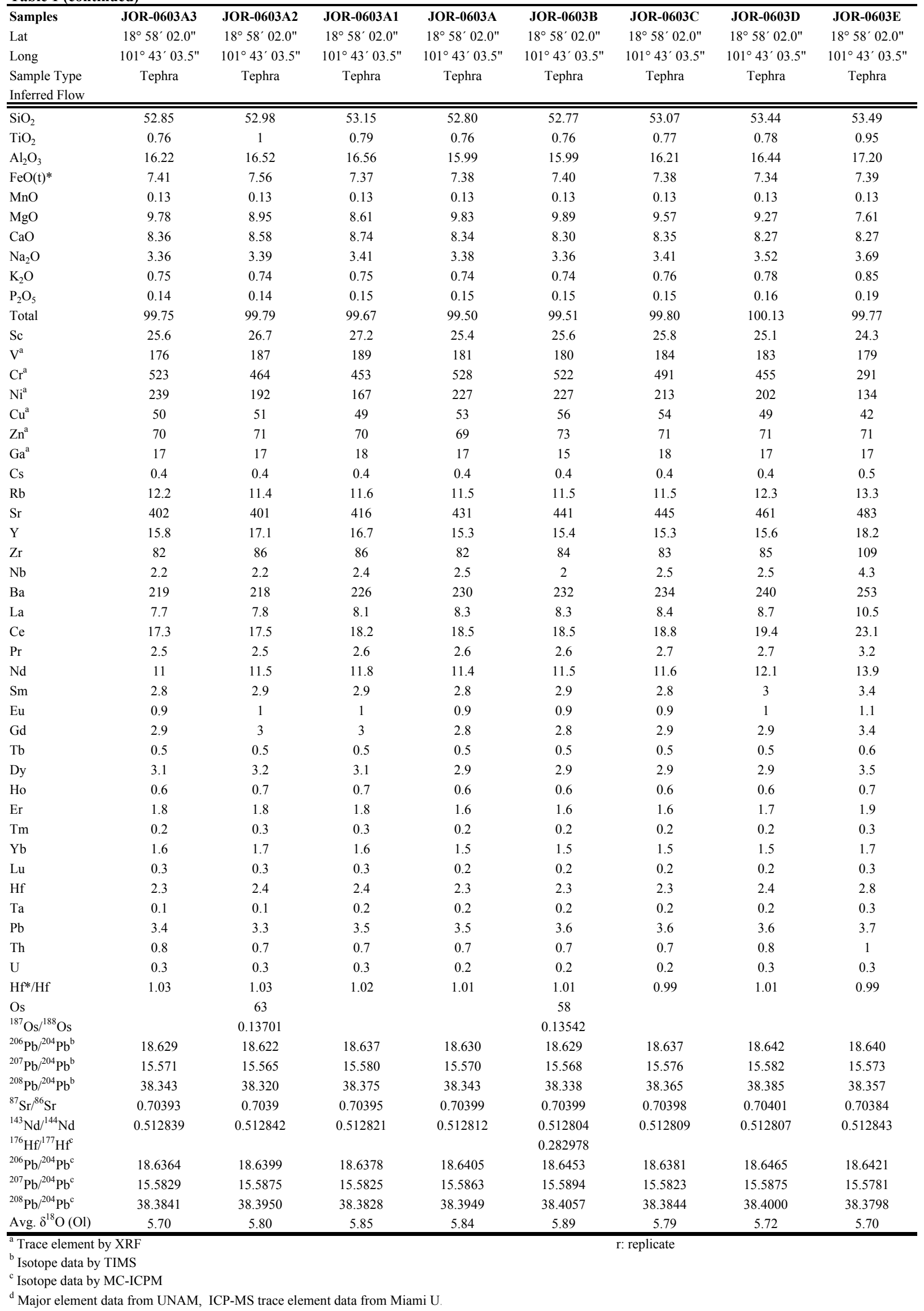


Table 1 (continued)

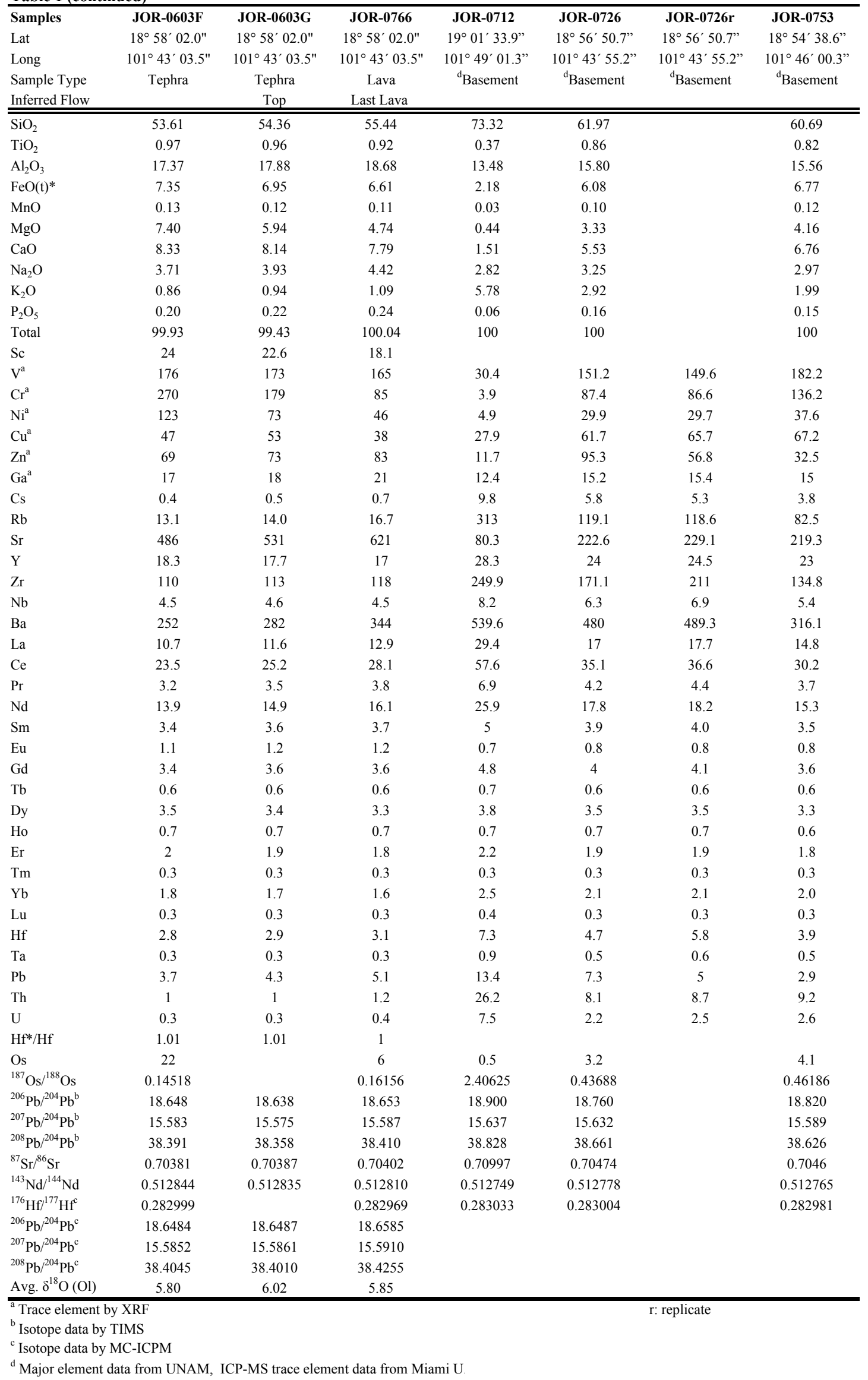

